RESEARCH PAPER RP1472 Part of Journal of Research of the National Bureau of Standards, Volume 28,
May 1942

\title{
PROPERTIES OF HIGH-PURITY IRON
}

\author{
By Harold E. Cleaves and John M. Hiegel
}

\section{ABSTRACT}

Results are recorded of new determinations of the workability, microstructure, density, and the thermal, mechanical, electrical, and magnetic properties of high-purity iron, in which the maximum amount of an individual impurity was 0.004 percent and the total of impurities in any specimen was 0.01 percent or less.

\section{CONTENTS}

II. Hot- and cold-working characteristics _.

III. Microstructure _. _ _ _ _ _ _

IV. Density _.......

V. Thermal properties

1. Freezing point

2. Alpha-gamma transformation

3. Thermal expansion

VI. Mechanical properties

1. Tensile properties.

2. Identation hardness ..........

3. Modulus of elasticity

VII. Electrical properties_._.

1. Resistivity . . 661

2. Temperature coefficient of resistivity

3. Thermal electromotive force _...

VIII. Magnetic properties_....... 663

1. Magnetic saturation induction _.................. 664

2. Coercivity and maximum permeability ............. 664

IX. Summary _.._.

X. References......... 667

\section{INTRODUCTION}

Ferrous materials, from cast iron to complex alloy steels, are essentially impure irons, and their properties are the properties of the basic material, iron, modified by the presence of alloying elements and impurities or by factors such as heat treatment and mechanical work. Throughout the history of ferrous metallurgy, knowledge of the properties of "pure iron" has been regarded as essential to an understanding of the effects of different factors on the properties of known metals and to indicate the possibilities and limitations of new alloys or combinations. The need for accurate information is greater today than ever before to meet the demands for greater reliability and for improved or new properties in ferrous materials. 
Determinations of the properties of "pure iron" have been reported periodically throughout the literature of ferrous metallurgy. Each investigator was convinced that his iron was "pure iron" and that the results of his determinations were "the properties of pure iron", but the results of different investigators usually were not in agreement and frequently were widely divergent. Many of these differences may be ascribed to changing standards of what constitutes pure iron. Improved methods of analysis revealed the presence of previously unsuspected impurities, and improved testing technique showed that previously ignored amounts of impurities have surprising effects upon certain properties of the metal. For example, metallurgists know that the properties of iron are definitely affected by such small amounts as 0.001 percent of such elements as carbon, sulfur, and hydrogen, but it is only in recent years that the necessity for such precise analyses has been recognized and the procedure for making these analyses has been available. Consequently, modern high-purity irons presumably are of higher purity and certainly are of more definitely known purity than were the earlier "pure irons." The latter term should be reserved for elemental iron which is known to be free from all impurities, a material which has not yet been prepared, at least in useful amounts.

It would be expected that the quality of the products would have improved progressively in these continued attempts and that the properties of the different specimens would have come into better agreement. This occurred to some extent, but a review $[1]^{1}$ of available information showed that there is still a surprising amount of uncertainty in regard to the best or most probable values for such fundamental properties as the density, electric resistivity, and thermal expansion of iron. The reversible transformation of alpha to gamma iron at a moderately elevated temperature is a characteristic of iron which is of vital importance in industrial applications because it permits controlled alteration of the properties by suitable heat treatment. When available information was reviewed in 1935, not only was there uncertainty in regard to the temperature or temperatures at which the transformation occurred during heating and and during cooling, but, in addition, there was discussion of the hypothesis that the alpha-gamma transformation was a result of the presence of impurities and would not occur in pure iron.

This uncertainty in regard to the fundamental properties of iron induced the National Bureau of Standards to prepare iron of high purity, to definitely establish its composition, and to determine its properties. The preparation of the high-purity iron by recrystallization of ferric nitrate, conversion to ferric oxide, reduction to sponge iron, and melting under hydrogen and in a vacuum was described in previous publications $[2,3]$. Nineteen ingots were produced, approximately 1 pound each in weight. Careful analyses by spectrochemical and chemical methods yielded the results shown in table 1. This iron is noteworthy in the limited number of impurities whose presence could be detected. In general, nonmetallic elements constitute the major impurities; in seven of the ingots only one metallic impurity, copper, was found. The total of identified impurities ranges

\footnotetext{
${ }_{1}^{1}$ Figures in brackets indicate the literature references at the end of this paper.
} 
from 0.0083 to 0.0129 percent, with 13 of the 19 ingots having a content of less than 0.010 -percent total of impurities.

TABLE 1.-Compositions of ingots of high-purity iron

\begin{tabular}{|c|c|c|c|c|c|c|c|c|c|}
\hline \multirow{2}{*}{ Element ${ }^{1}$} & \multicolumn{9}{|c|}{ Ingot number } \\
\hline & 1 & 2 & 3 & 4 & 5 & 6 & 7 & 8 & 9 \\
\hline $\begin{array}{l}\mathrm{Cu} \\
\mathrm{Si} \\
\mathrm{Be} \\
\mathrm{B} 1 \\
\mathrm{~A} 1 \\
\mathrm{C} \\
\mathrm{S}\end{array}$ & $\begin{array}{c}<0.002 \\
.001 \\
<.001 \\
\text { nil } \\
<.001 \\
.002_{3}\end{array}$ & $\begin{array}{c}<0.002 \\
.001 \\
<.001 \\
\text { nil } \\
.001 \\
.0023\end{array}$ & $\begin{array}{c}<0.002 \\
.003 \\
<.001 \\
\text { nil } \\
.001 \\
.0026\end{array}$ & $\mid \begin{array}{l}<0.002 \\
.001 \\
\text { nil } \\
\text { nil } \\
.001 \\
.001\end{array}$ & $\mid \begin{array}{c}<0.002 \\
.003 \\
\text { nil } \\
<.001 \\
0.0010\end{array}$ & $\mid \begin{array}{c}<0.002 \\
001 \\
<.001 \\
\text { nil } \\
<.001 \\
.0013\end{array}$ & $\mid \begin{array}{c}<.002 \\
\text {.001 } \\
\text { nil } \\
\text { nil } \\
<.001 \\
.0021\end{array}$ & $\begin{array}{c}<0.002 \\
.001 \\
\text { nil } \\
\text { nil } \\
.0010\end{array}$ & $\begin{array}{l}<0.002 \\
\text { nil } \\
\text { nil } \\
\text { nil } \\
.0022_{2}\end{array}$ \\
\hline $\begin{array}{l}\mathrm{P} \\
\mathrm{O}_{2} \\
\mathrm{~N}_{2}\end{array}$ & $\begin{array}{c}.001_{3} \\
.000_{1} \\
.000_{1}\end{array}$ & $\mid \begin{array}{r}<.0005 \\
.0003 \\
.000_{2} \\
.000_{2}\end{array}$ & $\begin{array}{l}.000_{5} \\
.0004 \\
.000_{1}\end{array}$ & $\begin{array}{l}.0038 \\
.000_{4} \\
.000_{2}\end{array}$ & $\begin{array}{l}.0040_{0} \\
.0002 \\
.000_{2}\end{array}$ & $\begin{array}{r}.004_{5} \\
.000_{2} \\
.000_{2}\end{array}$ & $\begin{array}{l}.0020 \\
.000_{1} \\
.000_{2}\end{array}$ & $\begin{array}{l}.003_{2} \\
.000_{0} \\
.000_{2}\end{array}$ & $\begin{array}{l}.0035 \\
.0000 \\
.0001\end{array}$ \\
\hline $\begin{array}{l}\text { Total of identified im- } \\
\text { purities }\end{array}$ & $<0.009_{3}$ & $<0.008_{5}$ & $<0.011_{1}$ & $<0.009_{0}$ & $<0.012_{\theta}$ & $<0.011_{7}$ & $<0.008_{9}$ & $<0.008_{9}$ & $<0.009_{\mathrm{g}}$ \\
\hline
\end{tabular}

\begin{tabular}{|c|c|c|c|c|c|c|c|c|c|c|}
\hline \multirow{2}{*}{ Element1 } & \multicolumn{10}{|c|}{ Ingot number } \\
\hline & 10 & 11 & 12 & 13 & 14 & 15 & 16 & 17 & 18 & 19 \\
\hline $\begin{array}{l}\text { Cu } \\
\text { Si-. } \\
\text { Be } \\
\mathrm{Al}^{-} \\
\mathrm{C} \\
\mathrm{S}\end{array}$ & $\begin{array}{l}<0.002 \\
\text { nil } \\
\text { nil } \\
\text { nil } \\
.0028\end{array}$ & $\left|\begin{array}{c}<0.002 \\
\text { nil } \\
\text { nil } \\
\text { nil } \\
0001_{5}\end{array}\right|$ & $\begin{array}{c}<0.002 \\
.002 \\
\text { nil } \\
\text { nil } \\
<.001 \\
.001_{2}\end{array}$ & $\begin{array}{c}<0.002 \\
\text { nil } \\
\text { nil } \\
\text { nil } \\
<.001 \\
.002\end{array}$ & $\mid \begin{array}{c}<0.002 \\
.002 \\
\text { nil } \\
\text { nil } \\
.001 \\
.001_{1}\end{array}$ & $\mid$\begin{tabular}{c}
$<0.002$ \\
nil \\
nil \\
$<.001$ \\
\hdashline $.001_{3}$
\end{tabular} & $\mid$\begin{tabular}{l}
0.002 \\
nil \\
nil \\
nil \\
\hdashline $.004_{1}$
\end{tabular} & $\mid \begin{array}{c}<0.002 \\
<.001 \\
\text { nil } \\
\text { nil } \\
0.0025\end{array}$ & $\begin{array}{c}<0.002 \\
\text { nil } \\
\text { nil } \\
\text { nil } \\
.001 \\
.001_{1}\end{array}$ & $\begin{array}{c}<0.002 \\
\text { nil } \\
\text { nil } \\
\text { nil } \\
<.001 \\
.002\end{array}$ \\
\hline $\begin{array}{l}\mathrm{N}_{2} \\
\mathrm{H}_{2}\end{array}$ & $\begin{array}{l}.0019 \\
.000_{1} \\
.000_{1} \\
\end{array}$ & $\begin{array}{l}.004_{5} \\
.000_{2} \\
.000_{1} \\
\end{array}$ & $\begin{array}{l}.0014 \\
.000_{5} \\
.000_{2} \\
\end{array}$ & $\begin{array}{l}.004_{0} \\
.000_{3} \\
.000_{1} \\
\end{array}$ & $\begin{array}{l}.002_{0} \\
.000_{2} \\
.000_{1} \\
\end{array}$ & $\begin{array}{l}.0010 \\
.000_{6} \\
.000_{2} \\
\end{array}$ & $\begin{array}{r}.001_{2} \\
.000_{1} \\
.000_{1} \\
\end{array}$ & $\begin{array}{r}<.0005 \\
.0030 \\
.000_{3} \\
.000_{2}\end{array}$ & $\begin{array}{l}.0034 \\
.000_{1} \\
.000_{2}\end{array}$ & $\begin{array}{l}.004 \\
.000_{2} \\
.000_{2}\end{array}$ \\
\hline $\begin{array}{l}\text { Total of identi- } \\
\text { fied impurities }\end{array}$ & $<0.008_{4}$ & $<0.009_{8}$ & $<0.008_{8}$ & $<0.010_{3}$ & $<0.008_{9}$ & $<0.008_{5}$ & $<0.0090$ & $<0.010_{5}$ & $<0.008_{3}$ & $<0.010$ \\
\hline
\end{tabular}

1 The arc spectrum of each ingot was examined for the presence of sensitive lines of 49 elements. Determinations of $\mathrm{Cu}, \mathrm{Si}, \mathrm{Be}$, and $\mathrm{Al}$ are recorded above, the expression "nil" meaning that the amount of the impurity, if present at all, was less than the sensitivity of the analytical method. None of the following 45 elements could be identified in any of the ingots: Ag, As, $\mathrm{Au}, \mathrm{B}, \mathrm{Ba}, \mathrm{Bi}, \mathrm{Ca}, \mathrm{Cb}, \mathrm{Cd}, \mathrm{Ce}, \mathrm{Co}, \mathrm{C}_{1}, \mathrm{Ga}$, $\mathrm{Ge}, \mathrm{Hf}, \mathrm{Hg}$, In, Ir, K, Li, Mg, Mn, Mo, Na, Ni, Os, Pb, Pd, Pt, Rh, Ru, Sb, Sc, Sn, Sr, Ta, Th, Ti, Tl, U, V, W, Y, Zn, and Zr.

2 Each total of identified impurities includes 0.001 percent of carbon and 0.0005 percent of phosphorus, although these elements were not determined for all the ingots.

The determinations of the properties of this material have been made with the cooperation of other laboratories of the Bureau and of outside agencies. The size of the ingots was not sufficient to permit determination of all the properties on any one ingot. Instead, in most cases, each property was determined on specimens of several ingots selected to include a range of compositions. The present paper summarizes these determinations and compares the results with the data available from the review of 1935 and from subsequent publications.

\section{HOT- AND COLD-WORKING CHARACTERISTICS}

The ingots were prepared by allowing the vacuum-melted metal to solidify and cool in the furnace. The resulting ingots all contained concealed shrinkage cavities, which sometimes extended more than half the length of the ingot, and the metal had the coarsely crystalline structure which is characteristic of slowly cooled ferrite, as is shown in figure 1 . Some of the determinations of properties could be made 
on specimens sawed from the ingots, but most of the determinations required rod or wire specimens.

The procedure that was adopted to convert the ingot metal into rods, with minimum wastage, was first to quarter each ingot longitudinally and grind or machine the inner surface to remove any defective material in the vicinity of the pipe. The ingot sections were then hot-forged to break up the coarsely crystalline structure and to convert the triangular cross section to a square. The specimens were heated to about $800^{\circ} \mathrm{C}$ in an induction furnace prior to forging and whenever annealing of the rods was necessary in the subsequent operations. Oxide scale formed during the heating was removed by pickling in hydrochloric acid which contained a commercial inhibitor. Analyses showed that this procedure did not introduce oxygen or other contamination into the metal. The forged rods were cold-rolled and swaged to rods $6 \mathrm{~mm}$ or less in diameter. Wire specimens were prepared by drawing small swaged rods through sapphire dies. The wires were annealed in vacuum by passing a current through the wires suspended between two electrodes. The hot- and cold-working characteristics of most of the ingots were those of a reasonably ductile metal of high purity.

No difficulty was encountered in any of the hot-working operations, and most of the specimens responded satisfactorily to cold work with occasional annealing. Certain of the rods, however, developed cracks during rolling, and this tendency was more evident in subsequent swaging. In some cases the trouble could be cured by grinding out the transverse cracks or cropping the split ends and by modifying the annealing treatment and working schedule, but in other cases the cracking persisted in spite of all precautions. The tendency to crack could not be attributed to differences in composition of the different ingots nor to differences in the hot-or cold-working procedure. Some sections from certain ingots worked satisfactorily, whereas other sections of the same ingots developed difficulties. In a few instances, more or less difficulty was encountered in working all sections of a particular ingot.

It seems probable that the difficulties experienced in working some specimens are associated with the coarse-grained structure of the furnace-cooled ingots. These difficulties might have been avoided if the ingots had been chill-cast instead of slowly solidified and slowly cooled.

Adcock and Bristow [4] reported similar difficulties in working certain samples of their high-purity iron, and attributed this brittleness to the presence of microscopic spots or cavities in the grain boundaries. Naumann [5] also found that nodules existed in the grain boundaries of steel which had been embrittled by treatment in hydrogen under pressure and at elevated temperatures. Microscopic examination of the NBS iron, as described in the next section of this report, indicated that such imperfections at the grain boundaries as were observed in the iron were caused by the polishing and etching technique.

\section{MICROSTRUCTURE ${ }^{2}$}

The preparation of specimens of high-purity iron for microscopi examination was not entirely satisfactory when the conventiona

\footnotetext{
3 The study of the microstructure was made with the cooperation of T. D. Brown, of the Division o Metallurgy of this Bureau.
} 

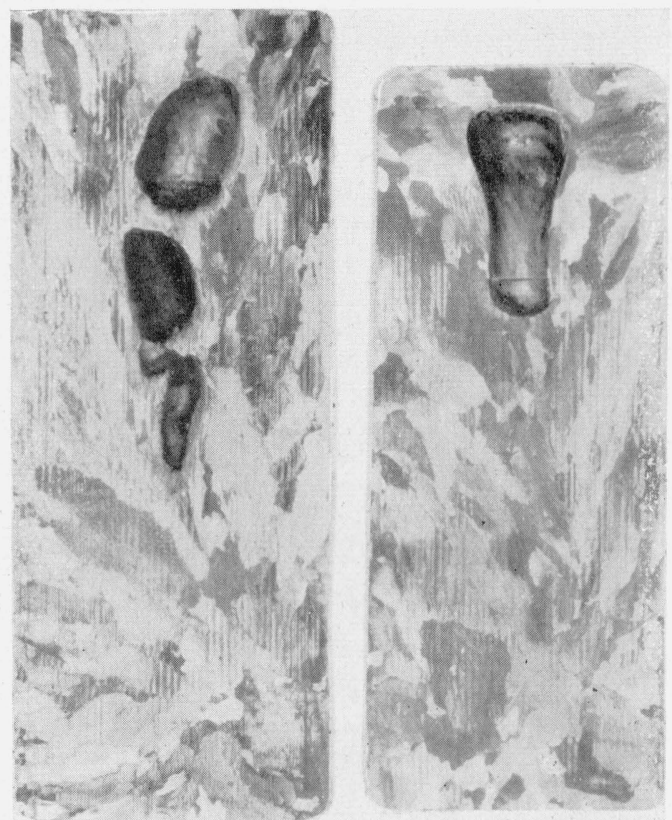

FIGURE 1.-Macrosections of two ingots of high-purity iron, showing the concealed pipes and coarsely crystalline structure.

Cold work from grinding caused the parallel lines. Etched with 1-percent nital. $\times 1$.

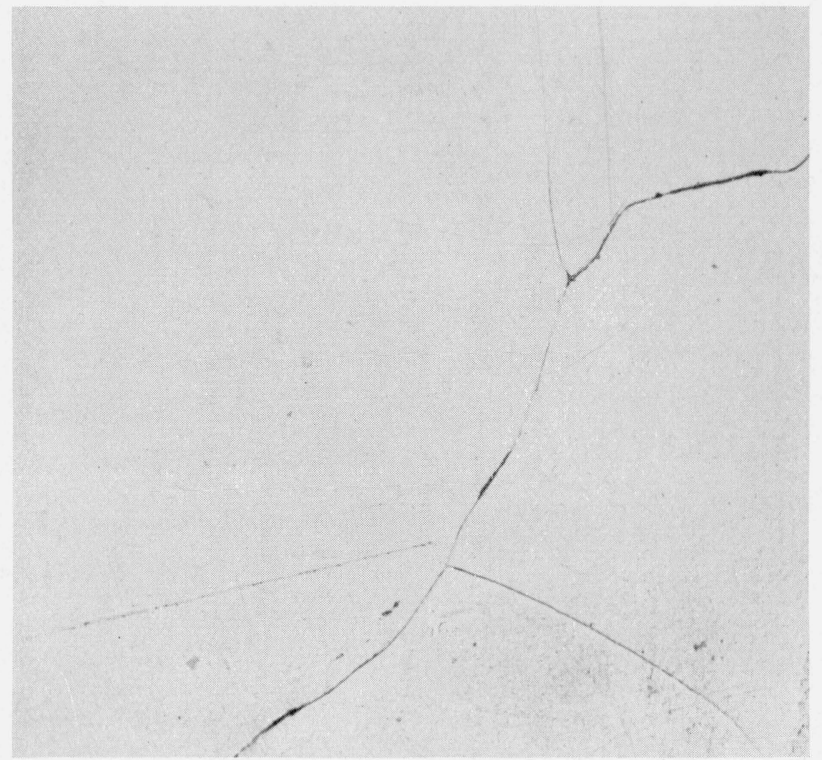

FIGURE 2.-Streaks on the grain boundaries of high-purity iron ground on a lap and polished with rouge.

Etched with 1-percent nital. $\times 250$. 


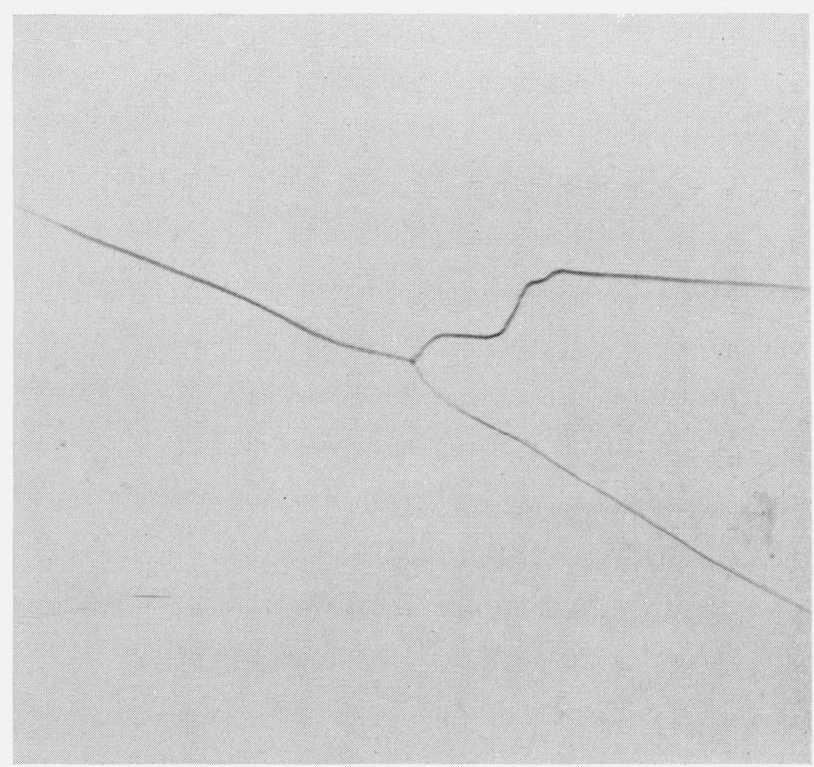

FIGURE 3.-Specinens prepared without using any abrasive or polishing compound were free from local defects, but the surfaces were not flat.

Etched with 1-percent nital. $\times 1000$.

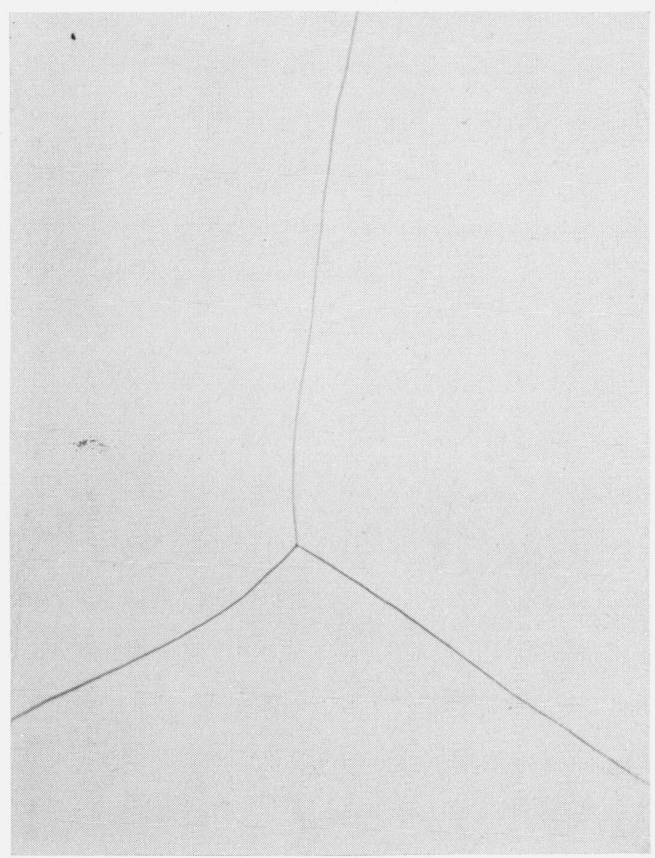

FiguRE 4.-Large, clean grains and sharply defined, clean grain boundaries ar typical of high-purity iron.

The specimen was-filed, lapped, and electrolytically polished. Etched with 1-percent nital. $\times 250$. 


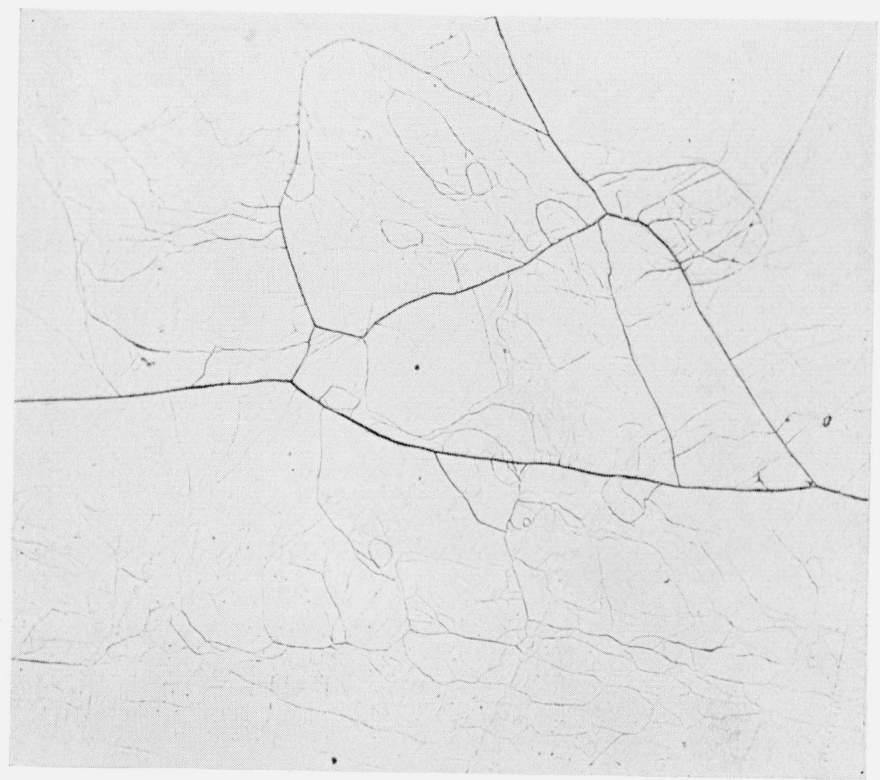

FiguRE 5.-Alpha veining in high-purity iron.

Etched with picric acid. $\times 100$.

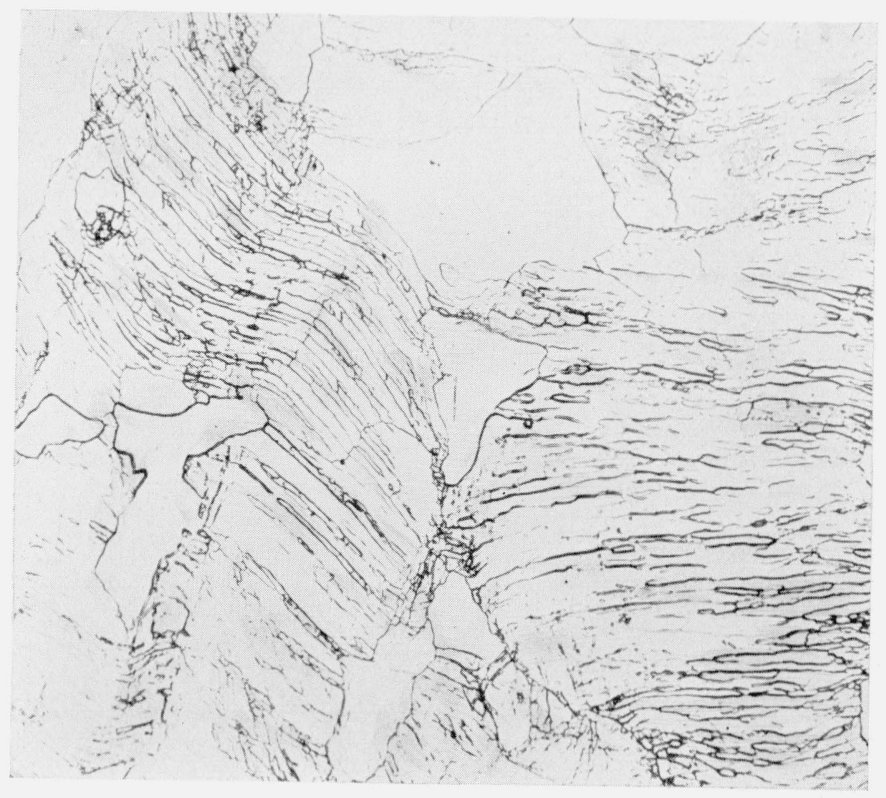

FIGURE 6.-Deformation bands produced in high-purity iron by cold work. Etched with picric acid. $\times 250$. 
methods of grinding on paper and subsequent wet polishing were employed. The surface of the specimen invariably was marred by particles of abrasive or by the pits which remained after the abrasive was removed by the etchant. These defects were observed both within the grains and at the grain boundaries, and in appearance resembled the spots or streaks to which other writers $[4,5]$ attributed the brittleness of some of their specimens. The use of metal laps instead of abrasive papers resulted in improvement, although some spots remained in the grain boundaries, as is illustrated in the micrographs published by Ellinger and Acken [6]. Streaks on the grain boundaries of high-purity iron ground on a lap and polished with rouge are illustrated in figure 2. Complete freedom from these defects was achieved by eliminating all abrasives and polishing compounds, that is, when the sawed surface was smoothed with a No. 4 file and then polished electrolytically. However, such surfaces were not flat; in fact, it was frequently difficult to get enough of the field in focus at one time to make a satisfactory picture. Figure 3 shows the appearance of a specimen prepared by filing and electrolytic polishing. This unmounted specimen was polished in an acetic-anhydride-perchloricacid electrolyte [7]. Equally good results for specimens mounted in bakelite were obtained when an orthophosphoric acid electrolyte [8] was used.

The best results, all things considered, were obtained by smoothing the specimen with a file, grinding on a lap just enough to produce a flat surface, and polishing electrolytically. Occasional pits and other surface defects resulted from this procedure, but, in general, the appearance of the high-purity iron revealed large clean grains with sharply defined, clean grain boundaries, as shown in figure 4. Comparison of figure 4 with figure 2 shows the effect, on the appearance of the same specimen, of variations in the grinding and polishing technique. These results indicate that the surface defects, particularly the defects in the grain boundaries, are caused by the grinding and polishing technique and are not inherent characteristics of this highpurity iron.

There were no definite differences in the microstructure of the different ingots which could be correlated with the variations in composition, or with the behavior in hot and cold working. Figure 4 actually represents a sample forged from ingot 16 but is typical of all the ingots.

Figure 5 illustrates alpha veining in specimens cut from the original ingots. The alpha veining must have developed when the ingot passed through the $A_{3}$ transformation in cooling from the molten state. No subsequent heat treatment was applied, and the only work on the material was the sawing of the specimen from the ingot. Alpha veining also was observed in specimens which had been worked and subsequently annealed at temperatures above $A_{3}$.

Cold working, without subsequent annealing, produced the deformation bands or worked structure illustrated in figure 6 . The majority of the grains in each specimen showed an unusual amount of deformation bands, but certain grains were entirely free from strain markings. This phenomenon, together with the variation in direction and intensity of the bands, obviously is associated with differences in the orientation of different grains.

$451601-42-6$ 
Further evidence indicating the ease of permanently altering the structure of high-purity iron by work hardening is found in the parallel markings in many of the grains in figure 1. The marks follow the direction of travel of the grinding wheel across the surface and most of the grains are thus affected, but a few grains are unmarked. The depth to which this effect had penetrated was shown by the fact that repeated polishing and etching of the surface failed to produce any noticeable change in the number or appearance of the markings.

\section{DENSITY ${ }^{3}$}

Determinations of the density of the high-purity iron were made on specimens representing different ingots and different conditions of cold work and heat treatment. Nineteen determinations ranged from 7.870 to $7.876 \mathrm{~g} / \mathrm{cm}^{3}$ at $20^{\circ} \mathrm{C}$. Observations of the density were made at room temperature, which varied from $23^{\circ}$ to $26^{\circ} \mathrm{C}$ during these experiments. The observed values have been corrected to $20^{\circ} \mathrm{C}$ by means of the coefficient of expansion. The same range of values was obtained from $6-\mathrm{mm}$ rods and from specimens of $2-\mathrm{mm}$ wire. The values obtained from rods which had been swaged to 20-percent reduction in area were not altered beyond the limit of precision of the determination, \pm 0.002 percent, by annealing in vacuum at $870^{\circ} \mathrm{C}$ for $1 \frac{1}{2}$ hours. Likewise, surface grinding of the swaged rods, to produce true cylinders of circular cross section, did not appreciably affect the density values. Half or quarter sections of two of the ingots yielded values of 7.872 and 7.873 at $20^{\circ} \mathrm{C}$, identical with the mean of all the values.

In summarizing these results, the higher values appear to be more reliable than the lower ones within this range. Concealed pipes or spongy areas would lead to low density values for the ingot material. Cracks in worked material also would result in low density values. It is concluded, therefore, that the best value for the density of highpurity iron is the mean of the 15 highest observed values, that is, $7.874 \pm 0.001 \mathrm{~g} / \mathrm{cm}^{3}$ at $20^{\circ} \mathrm{C}$.

A review of the literature [1] in 1935 indicated that the rounded value, 7.87 , was the best approximation then available for the density of iron. Adcock and Bristow [4] subsequently reported that the density of their high-purity iron, in the annealed condition after being cold-worked, was $7.871 \pm 0.002$ at $19^{\circ} \mathrm{C}$. The new value, 7.874 $\pm 0.001 \mathrm{~g} / \mathrm{cm}^{3}$ at $20^{\circ} \mathrm{C}$, is slightly higher than these previous values.

\section{THERMAL PROPERTIES}

\section{FREEZING POINT 4}

Portions of ingots 3 and 15 were melted and allowed to solidify in beryllia crucibles in atmospheres of helium and hydrogen, and in vacuum. The temperatures were measured by means of an optical pyrometer sighted into a refractory black body immersed in the molten metal. Roeser and Wensel found that in vacuum the iron vapor in the line of sight absorbed about 2 percent of the light, corresponding to a reduction of $2^{\circ}$ to $3^{\circ} \mathrm{C}$. Therefore, the results obtained in

3 The density determinations were made under the direction of E. L. Peffer, of the Weights and Measures Division of this Bureau.

${ }_{4}^{4}$ The freezing point determinations were made by Wm. F. Roeser and H. T. Wensel, of the Pyrometry Section of this Bureau, as described elsewhere [9]. 
vacuum were excluded. The values obtained in helium and in hydrogen are given in the following tabulation.

\begin{tabular}{|c|c|c|c|}
\hline \multirow{2}{*}{$\begin{array}{l}\text { Ingot } \\
\text { No. }\end{array}$} & \multirow{2}{*}{$\begin{array}{c}\text { Total } \\
\text { Impurities }\end{array}$} & \multicolumn{2}{|c|}{ Freezing point } \\
\hline & & In helium & In hydrogen \\
\hline $\begin{array}{r}15 \\
3\end{array}$ & $\begin{array}{c}\text { Percent } \\
0.0083 \\
.0111\end{array}$ & $\begin{array}{c}\circ C \\
1538.9 \\
1538.7\end{array}$ & $\begin{array}{c}\circ C \\
1537.9 \\
1538.0\end{array}$ \\
\hline
\end{tabular}

The freezing point in hydrogen was about $1^{\circ} \mathrm{C}$ lower than the freezing point in helium, probably an effect of the solubility of hydrogen in molten iron. The variation in composition of the two ingots did not appreciably affect the freezing points, but the freezing point of pure iron probably would be slightly higher than that of the highpurity iron, which contained approximately 0.01 percent of impurities. Wensel and Roeser therefore concluded that the freezing point of pure iron would be $1,539^{\circ} \pm 1^{\circ} \mathrm{C}$.

This figure is $4^{\circ} \mathrm{C}$ higher than the value selected in the review of the literature [1] in 1935. Chipman and Marshall [10] recently determined the melting point in hydrogen of a sample of carbonyl iron. The presence of impurities, such as 0.031 percent of nickel, in the carbonyl iron and the presence of hydrogen may account for the fact that Chipman and Marshall's result is $4^{\circ} \mathrm{C}$ lower than the value of $1,539^{\circ} \pm 1^{\circ} \mathrm{C}$ which was obtained by Roeser and Wensel.

\section{ALPHA-GAMMA TRANSFORMATION ${ }^{5}$}

The review [1] of the literature up to 1935 led to the conclusion that "the rounded value $910^{\circ} \mathrm{C}$ is probably the best present approximation of the temperature of the $A_{3}$ transformation of iron." At that time it appeared that the difference between $A c_{3}$ and $A r_{3}$ in high-purity metal, that is, the difference between the temperatures at which the transformation occurred on heating and on cooling - could be roduced to $1^{\circ}$ or $2^{\circ} \mathrm{C}$ by heating and cooling at very slow rates. Yensen had proposed the hypothesis that the $A_{3}$ transformation was a function of impurities, and some support had been afforded to this hypothesis by the reported observations of $A_{3}$ temperatures appreciably higher than $910^{\circ} \mathrm{C}$ by Hensel and Larsen, and by Austin and Pierce.

Several determinations of the temperature of the $A_{3}$ transformation in high-purity iron have been reported since 1935. Wells, Ackley, and Mehl [11] determined the $A_{3}$ temperature in hydrogen-purified carbonyl iron, by a dilatometric method, and found that the transformation occurred at $909.5^{\circ} \pm 1^{\circ} \mathrm{C}$. This confirmed their preliminary report, which was included in "The Metal-Iron" [1]. In the discussion of their paper, Austin reported that a pyrometric error had been discovered in the procedure employed by Austin and Pierce and that the previously reported high results should be reduced from $928^{\circ}$ to $910^{\circ} \mathrm{C}$. On the other hand, Adcock and Bristow [4] reported

\footnotetext{
${ }_{5}$ The determinations of the temperature of the alpha-gamma transformation were made by S. J. Rosenberg, of the Division of Metallurgy of this Bureau; by J. B. Austin, of the United States Steel Corporation Research Laboratory; and by B. A. Rogers and K. O. Stamm, of the U. S. Bureau of Mines.
} 
that the $A c_{3}$ transformation in their highest-purity iron began at $924^{\circ} \mathrm{C}$. Esser [12] found that the temperature of the $A_{3}$ transformation increased with increasing purity, up to $932^{\circ} \mathrm{C}$, and suggested that the allotropy of iron is an imposed, not an inherent, characteristic. Esser remarked that iron sufficiently pure so that $A_{3}$ and $A_{4}$ would merge, as suggested by Yensen, had not yet been obtained. Esser and Eusterbrock [13] used an improved dilatometer and found that the $\mathrm{Ac}_{3}$ temperature in vacuum-melted electrolytic iron increased with decreasing carbon content, from $917^{\circ} \mathrm{C}$ for material which contained 0.01 percent of carbon, to $935^{\circ} \mathrm{C}$ when the carbon content was only 0.004 percent. However, other recent determinations do not substantiate these high values. Smith [14] converted ferric nitrate to metallic iron by chemical methods and found, by X-ray methods, that this material transformed at $907^{\circ}$ to $908^{\circ} \mathrm{C}$. Wangsgard [15] also used X-ray methods and found that a specimen of hydrogen-purified carbonyl iron transformed at $910.5^{\circ} \pm 0.6^{\circ} \mathrm{C}$.

Considerable attention was devoted to the study of the alphagamma transformation in the high-purity iron because of this uncertainty as to the temperature at which $A_{3}$ occurs, as shown in the preceding paragraphs. Determinations by thermal analysis were made at this Bureau, and dilatometric and magnetometric determinations were made in other laboratories.

Heating and cooling curves of specimens cut from three of the ingots, Nos. 3, 6, and 18, were obtained by S. J. Rosenberg, using the method described by Scott and Freeman [16], with the following modifications: an improved temperature gradient was obtained by rewinding the furnace; the thermocouple wires were spot-welded to the specimen; inverse rate curves were computed from observations of the time-temperature relations.

The rates of heating or cooling through the transformation range varied slightly from run to run, from a minimum rate of $0.5^{\circ} \mathrm{C}$ per minute to a maximum of $1.2^{\circ} \mathrm{C}$ per minute. Within this range there was no effect of the rate of heating or cooling on the temperature of the transformation. The inverse rate curves usually were sharply defined, as is illustrated by the curves for irons 3 and 18 in figure 7 . Minor irregularities in the shape of the heating curves, such as the split transformation of iron 6 (fig. 7), were occasionally encountered. The irregular behavior was confined to the first run except in the two specimens of iron 6 , which exhibited irregularities in repeated runs. No correlation could be established between the irregular behavior and factors such as the composition of the ingot, the presence of mechanical strains from cold working, or the rate of heating and cooling. Furthermore, in the dilatometric determinations in other laboratories, irregularities were not observed in specimens of ingot 6 , but difficulties were encountered with iron 3 . Consequently, it appears that these difficulties or irregularities in both methods apply to individual samples or to individual runs, not to the ingot material or to the methods in general.

The results obtained by thermal analysis are listed in table 2 . The mean of all the $A c_{3}$ determinations is fractionally higher than $910^{\circ} \mathrm{C}$, and the mean of the three determinations for iron 18, which has the lowest total of impurities of the three ingots, is $911^{\circ} \mathrm{C}$. However, the data probably do not justify a more precise statement than that $A c_{3}$ in these irons occurs at $910^{\circ} \mathrm{C}$ and $A r_{3}$ at $900^{\circ} \mathrm{C}$. 


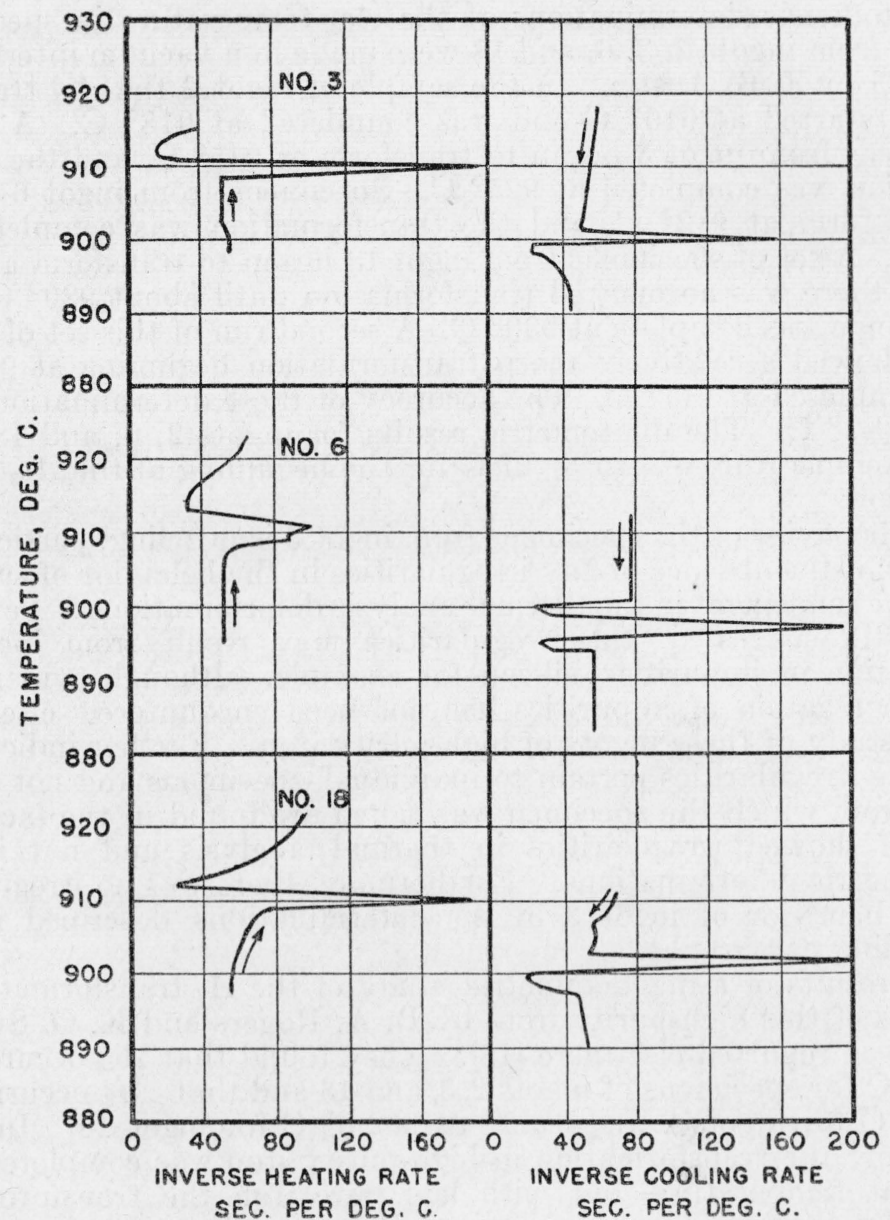

FIgURe 7.-Inverse rate curves for $A_{3}$ in high-purity irons. (Rosenberg).

TABLE 2.-The $A_{3}$ temperature in high-purity iron, as determined by thermal analysis (Rosenberg)

\begin{tabular}{|c|c|c|c|c|}
\hline Ingot & $\begin{array}{l}\text { Acs tem- } \\
\text { perature }\end{array}$ & $\begin{array}{l}\text { Heating } \\
\text { rate }\end{array}$ & $\begin{array}{l}A r_{3} \text { tem- } \\
\text { perature }\end{array}$ & $\begin{array}{l}\text { Cooling } \\
\text { rate }\end{array}$ \\
\hline & ${ }^{\circ} C$ & ${ }^{\circ} \mathrm{C} / \mathrm{min}$. & ${ }^{\circ} C$ & ${ }^{\circ} \mathrm{C} / \mathrm{min}$ \\
\hline $3 \ldots$ & $\left\{\begin{array}{l}911 \\
910 \\
908 \\
910\end{array}\right.$ & $\begin{array}{r}0.7 \\
.8 \\
.9 \\
1.2\end{array}$ & $\begin{array}{l}900 \\
900 \\
900 \\
901\end{array}$ & $\begin{array}{l}0.8 \\
1.0 \\
1.0 \\
1.1\end{array}$ \\
\hline $6 \ldots$ & $\left\{\begin{array}{l}911 \\
911 \\
909 \\
911\end{array}\right.$ & $\begin{array}{l}0.9 \\
1.1 \\
1.1 \\
1.2\end{array}$ & $\begin{array}{l}897 \\
898 \\
900 \\
899\end{array}$ & $\begin{array}{r}0.8 \\
.8 \\
1.0 \\
1.2 \\
1.2\end{array}$ \\
\hline $18 .-$ & $\begin{array}{l}911 \\
912 \\
910\end{array}$ & $\begin{array}{r}0.5 \\
.8 \\
1.0\end{array}$ & $\begin{array}{l}904 \\
902 \\
903\end{array}$ & $\begin{array}{l}0.7 \\
1.0 \\
1.2\end{array}$ \\
\hline Mean of all determinations....... & 910 & & 900 & $\ldots$ \\
\hline
\end{tabular}


Dilatometric determinations of the $A c_{3}$ temperature in specimens of rods from ingots $2,3,6$, and 18 were made in a vacuum in terferometer [17] by J. B. Austin. In the sample of ingot 2 the $A c_{3}$ transformation started at $910^{\circ} \mathrm{C}$ and was completed at $918^{\circ} \mathrm{C}$. A set of specimens from ingot 3 began to transform at $915^{\circ} \mathrm{C}$, and the transformation was completed at $925^{\circ} \mathrm{C}$. Specimens from ingot 6 began to transform at $912^{\circ} \mathrm{C}$, and the transformation was completed at $918^{\circ} \mathrm{C}$. A set of specimens from ingot 18 began to transform at $910^{\circ}$ $\mathrm{C}$, but there was no marked transformation until about $920^{\circ} \mathrm{C}$, and the change was complete at $930^{\circ} \mathrm{C}$. A second run of this set of specimens showed a relatively sharp transformation beginning at $909^{\circ} \mathrm{C}$ and completed at $917^{\circ} \mathrm{C}$. The accuracy of these determinations was about $\pm 2^{\circ} \mathrm{C}$. The dilatometric results for ingots 2,6 , and 18 indicate a temperature of $910^{\circ} \pm 2^{\circ} \mathrm{C}$ for the beginning of the $A c_{3}$ transformation.

The behavior of the specimens from ingot 3 is puzzling, particularly in view of the absence of any irregularities in the behavior of samples from the same ingot in the thermal-analysis determinations. Perhaps, as Austin suggested, the irregularities may result from localized segregation of impurities, silicon for example, although evidence of such segregation of impurities has not been encountered elsewhere in the study of these ingots of high-purity iron. Further indications that the irregularities pertain to individual specimens and not to the ingot from which the specimen was taken are found in the fact that ingot 6 showed irregularities in thermal analysis and not in the dilatometric determinations. Furthermore, there was no irregularity in the behavior of ingot 3 in the determinations described in the succeeding paragraphs.

The results of a magnetometric study of the $A_{3}$ transformation in samples of this high-purity iron, by B. A. Rogers and K. O. Stamm, have been reported elsewhere [18]. They found that $A c_{3}$ occurred at $910.5^{\circ} \mathrm{C}$ for specimens of ingots 2,3 , and 18 and that $A r_{3}$ occurred at $902.5^{\circ} \mathrm{C}$ for ingots 2 and 3 and at $902.0^{\circ} \mathrm{C}$ for ingot 18 . In their procedure the transformation in high-purity iron was completed at a constant temperature, but with less pure iron the transformation covered a range of several degrees. Rogers and Stamm found that the rate of the $A_{c}$ transformation was so slow that several hours were required to complete the change from the alpha to the gamma condition. The rate of the $A r_{3}$ transformation was perhaps three or four times that of the $A c_{3}$ change. The presence of a small amount of oxide caused $\mathrm{Ac}_{3}$ to begin several degrees below its normal temperature and end several degrees above it, but did not appreciably affect the $A r_{3}$ transformation. Their data indicate that the $A c_{3}$ transformation in this iron will complete itself at a fixed temperature, which is in the vicinity of $910.5^{\circ} \mathrm{C}$, and that $A r_{3}$ occurs at about $902.5^{\circ} \mathrm{C}$.

The results obtained by the three methods are not in perfect agreement-for example, the magnetometric method shows that $A c_{3}$ is completed at constant temperature, whereas the transformation extends over a few degrees in the thermal-analysis experiments and over a greater range in the dilatometric observations. All three methods are in agreement, however, that the $A c_{3}$ transformation in this high-purity iron occurs at $910^{\circ}$ to $910.5^{\circ} \mathrm{C}$ and that the $A r_{3}$ transformation is about $8^{\circ} \mathrm{C}$ lower than $A c_{3}$, even with very slow rates of cooling. Irregularities in a few of the determinations are 
ascribed to unknown features of the individual specimen or the individual determination, rather than to the compositions of the ingots from which the specimens were taken.

\section{THERMAL EXPANSION ${ }^{6}$}

Determinations of the linear thermal expansion of high-purity iron over the temperature range from -130 to $+900^{\circ} \mathrm{C}$ were made by $\mathrm{P}$. Hidnert, using the precision-comparator type of apparatus [19]. Measurements at temperatures below $300^{\circ} \mathrm{C}$ were made in air, those above $300^{\circ} \mathrm{C}$ were made in helium. It was not practicable to cover the complete temperature range in a continuous run with a single specimen. Furthermore there was some oxidation of the specimens, in spite of the helium atmosphere, and occasionally a specimen which had been exposed to temperatures near $900^{\circ} \mathrm{C}$ was permanently warped. For these reasons several rods, from ingots 4 and 18, were used to cover overlapping sections of the temperature range. Attempts to protect the rods, during exposure to high temperatures, by a thin coating of electroplated gold were not entirely successful. The gold plate blistered and broke at relatively low temperatures and tended to draw up into beads or disappear altogether at higher temperatures. The best results at temperatures above $300^{\circ} \mathrm{C}$ were obtained from rods which had been annealed previously for $1 \frac{1}{2}$ hours at $870^{\circ} \mathrm{C}$ in vacuum.

The summary of results in table 3 includes a number of average values for temperature ranges that were covered in more than one run, and a few results of single determinations. Duplicate determinations, on heating and on cooling the same specimen, or in overlapping runs with different specimens, invariably agreed within a fraction of 1 millionth per degree centigrade. The data from table 3, plotted for the mean temperature of each interval, define the smoothly continuous curve shown in figure 8, the shape of which is in accord with the effect of temperature on other properties of iron. Particular attention was paid to the temperature range from 0 to $-125^{\circ} \mathrm{C}$, but no evidence was observed of the irregular behavior reported by Simon and Bergman and discussed in "The Metal-Iron" [1].

TABLE 3.-Mean coefficient of linear thermal expansion of high-purity iron between $-130^{\circ}$ and $+900^{\circ} \mathrm{C}$ (Hidnert)

\begin{tabular}{|c|c|}
\hline $\begin{array}{c}\text { Temperature } \\
\text { interval }\end{array}$ & $\begin{array}{l}\text { Mean coefficient of linear thermal } \\
\text { expansion }\end{array}$ \\
\hline 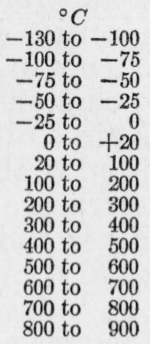 & $\begin{array}{c}\text { Millionths per }{ }^{\circ} \mathrm{C} \\
8.7 \\
9.5 \\
10.2 \\
10.8 \\
11.1 \\
11.5 \mathrm{5} \\
12.3 \\
13.3 \\
14.5 \\
15.5 \\
16.2 \\
16.15 \\
15.8 \\
15.8 \\
15.4\end{array}$ \\
\hline
\end{tabular}

6 The thermal expansion of the iron was investigated by P. Hidnert, W. B. Emerson, and J. B. Saunders, of this Bureau; by F. C. Nix and D. MacNair, of the Bell Telephone Laboratories; and by J. B. A ustin, of the United States Steel Corporation Research Laboratory. 


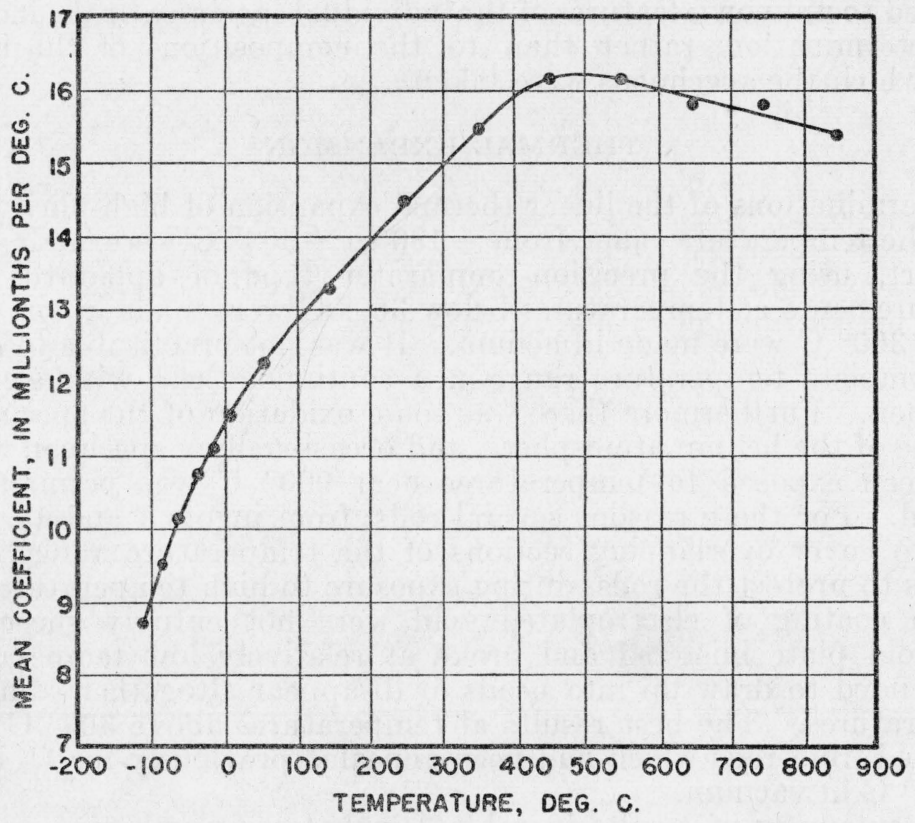

FIGURE 8.-Linear thermal expansion of high-purity iron between $-130^{\circ}$ and $+900^{\circ} \mathrm{C}$ (Hidnert).

The thermal expansion of specimens of ingots 2,6 , and 18 was studied, by means of an interferometric dilatometer, by F. C. Nix and D. MacNair. Specimens 6 and 18 were used at temperatures from $-180^{\circ} \mathrm{C}$ to room temperature, and specimens from ingot 2 were used from $-180^{\circ}$ to $+680^{\circ} \mathrm{C}$, as described in a recent publication [20]. The results of all three runs at low temperatures were in excellent agreement among themselves and with Hidnert's results. However, at temperatures above $0^{\circ} \mathrm{C}$, the coefficient-temperature curve of Nix and MacNair shows reversals of curvature which produce divergences of almost a millionth per degree centigrade from Hidnert's results. At temperatures above $500^{\circ}$ or $600^{\circ} \mathrm{C}$ such differences may be attributed to experimental difficulties at high temperatures, but a difference of $0.8 \times 10^{-6}$ at $125^{\circ} \mathrm{C}$ is not so simply explained.

Nix and MacNair [20] suggest that these irregularities are evidence of the beginning of the Curie transition at temperatures of about $0^{\circ} \mathrm{C}$, but there is no evidence of these irregularities in Hidnert's data. Hidnert's use of mean coefficients would tend to smooth out slight irregularities in his curve but would not eliminate reversals of the magnitude observed by Nix and MacNair. Similar reversals in curvature, but at higher temperatures, existed in the results of Austin and Pierce [21,] and slight reversals in curvature occurred between $40^{\circ}$ and $200^{\circ} \mathrm{C}$ in the recent results of Esser and Eusterbrock [13]. Some observations of thermal expansion by J. B. Austin in the course of his determinations of the temperature $A_{3}$ indicate a definite "plateau" at about $100^{\circ}$ to $125^{\circ} \mathrm{C}$ in plots of the true coefficient of expansion of specimens of irons 2 and 18.

Additional data on the expansivity of high-purity iron in the temperature range from $25^{\circ}$ to $250^{\circ} \mathrm{C}$ were obtained at the Bureau by 
W. B. Emerson and by J. B. Saunders. Emerson measured the thermal expansion of iron 18 by means of the interferometric dilatometer described by Merritt [22], and Saunders applied his own interferometric procedure [23] to irons 2 and 18 . The true coefficients of linear thermal expansion were derived mathematically from both sets of data to eliminate the smoothing effect which presumably exists when the mean coefficients are used.

Cubical equations computed from both sets of data satisfactorily expressed the linear thermal expansion of the iron, as was shown by agreement, within the experimental error, of the observed values and the values computed from the equations. The true coefficients of linear thermal expansion were obtained by differentiation of these equations. Similar computations were made for Hidnert's data for the temperature range $25^{\circ}$ to $250^{\circ} \mathrm{C}$; but an equation was not derived for the entire temperature range covered by Hidnert's data, as the equations required would be too complex to be useful.

TABLE 4.-True coefficient of linear thermal expansion of high-purity iron between $25^{\circ}$ and $250^{\circ} \mathrm{C}$

\begin{tabular}{|c|c|c|c|c|}
\hline Temperature & $\begin{array}{c}\text { Iron 2 } \\
\text { (Saunders) }\end{array}$ & $\begin{array}{c}\text { Iron } 18 \\
\text { (Saunders) }\end{array}$ & $\begin{array}{c}\text { Iron 18 } \\
\text { (Emerson) }\end{array}$ & $\begin{array}{l}\text { Iron } 18 \\
\text { (Hidnert) }\end{array}$ \\
\hline $\begin{array}{l}{ }^{2}{ }^{C} \\
100 \\
150 \\
150\end{array}$ & $\begin{array}{r}\text { millionths } \\
\text { per }{ }^{C} \\
\text { 11. } 58 \\
\text { 11. } 93 \\
\text { 12. } 27 \\
12.61 \\
12.94 \\
13.27 \\
13.59 \\
13.91 \\
14.21 \\
14.50\end{array}$ & $\begin{array}{r}\text { millionths } \\
\text { per }{ }^{\circ} \mathrm{C} \\
\text { 11. } 58 \\
\text { 11. } 93 \\
12.29 \\
12.64 \\
12.97 \\
13.30 \\
13.62 \\
13.93 \\
14.24 \\
14.54\end{array}$ & $\begin{array}{r}\text { millionths } \\
\text { per }{ }^{\circ} \\
11.97 \\
\text { 12. } \\
12.49 \\
12.74 \\
13.00 \\
13.26 \\
13.51 \\
13.78 \\
14.03 \\
14.29\end{array}$ & $\begin{array}{l}\text { millionths } \\
\text { per }{ }^{\circ} \\
11.90 \\
12.18 \\
12.48 \\
12.78 \\
13.08 \\
13.37 \\
13.67 \\
13.97 \\
14.26 \\
14.56\end{array}$ \\
\hline
\end{tabular}

The true coefficients thus computed from the observations of Emerson, Saunders, and Hidnert are listed in table 4. All are in good agreement, as is shown in figure 9, although the plot of Saunders,

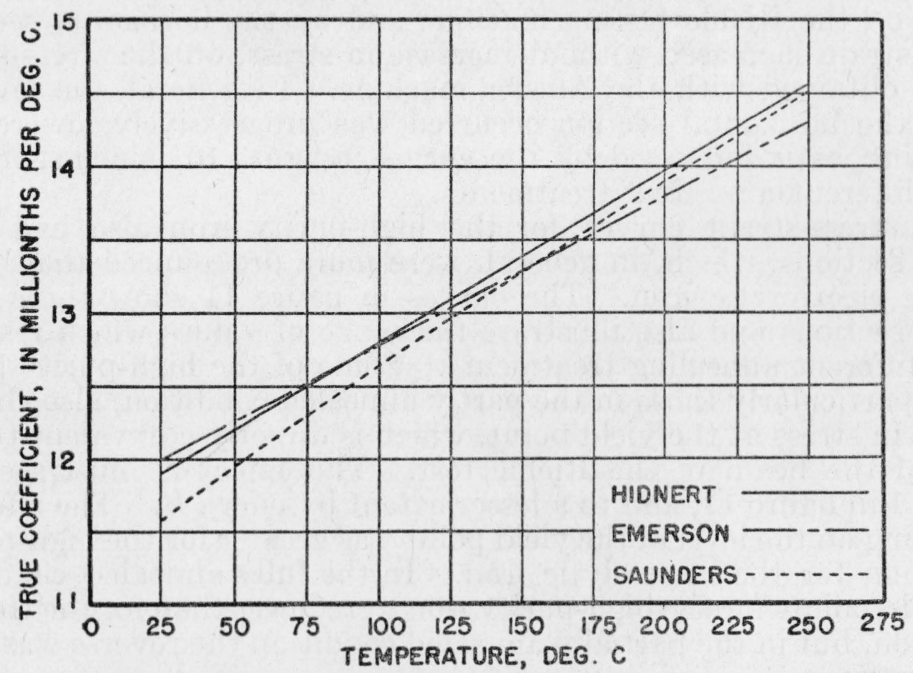

FIGURe 9.-Linear thermal expansion of high-purity iron between room temperature and $+250^{\circ} C$ (Hidnert, Saunders, Emerson). 
results shows some curvature whereas Hidnert's and Emerson's results are almost linear. In none of these runs is there any evidence of irregularities.

The data obtained at the Bureau and by Nix and MacNair indicate that the coefficient of linear thermal expansion of this iron at $20^{\circ} \mathrm{C}$ is $11.7 \pm 0.2 \times 10^{-6}$ per degree centigrade. The thermal expansion at low temperatures, where the data are in good agreement, is essentially as indicated by the mean coefficients obtained by Hidnert. The expansivity of the iron at high temperatures is not satisfactorily established by the data available.

\section{MECHANICAL PROPERTIES}

\section{TENSILE PROPERTIES 7}

The yield point of high-purity iron is of particular interest in view of the suggestion that it is a function of impurities and that pure iron, like the nonferrous metals, will not have a yield point.

The yield point in metals has been variously defined, from the load at which a "drop of the beam" was obtained, to the more modern definition that it is "the stress at which a marked increase in strain occurs without an increase in stress" [24]. The stress-strain curve presented by Adcock and Bristow [4] did not exhibit an increase in strain without an increase in stress, hence their conclusion that their iron did not have a yield point. In the present investigation, only a limited number of rods was available and it was desired to obtain other values as well as the yield point from each specimen. Consequently it was decided to study the stress-strain relations according to the ASTM definition, by means of an Amsler testing machine equipped with a Baldwin-Southwark stress-strain recorder. Rods of highpurity iron, swaged to $1 / 4$ inch in diameter with the central portion of each rod further reduced about 0.004 inch by grinding, were used and, for comparison, specimens of electrolytic iron. The electrolytic iron had a definite yield point, as was shown by the drop in the beam when pulled on the Riehle testing machine and by the horizontal section, where strain increased without increase in stress, on the stress-strain curves obtained with the Amsler machine. In general, the level at which the horizontal section occurred was progressively lowered by annealing, as is indicated by the curves in figure 10, which represent three different annealing treatments.

The stress-strain curves for the high-purity iron also had horizontal sections, which, in general, were more pronounced than those for the electrolytic iron. The curves in figure 11 show these horizontal sections and also illustrate the range of values which resulted from different annealing treatments. Some of the high-purity specimens, particularly those in the partly annealed condition, also showed a drop in stress at the yield point, which is directly equivalent to the drop of the beam in the Riehle test. This effect is illustrated by curve $A$ in figure 11, and to a lesser extent by curve $B$. The effect of annealing on the level of the yield point was greater for the high-purity iron than for the electrolytic iron. In the fully annealed condition the yield points for the high-purity iron were lower than for the electrolytic iron, but in the partially annealed condition the reverse was true.

7 The tensile properties were determined with the cooperation of G. F. Wohlgemuth, of the Metallurgical Division of this Bureau. 


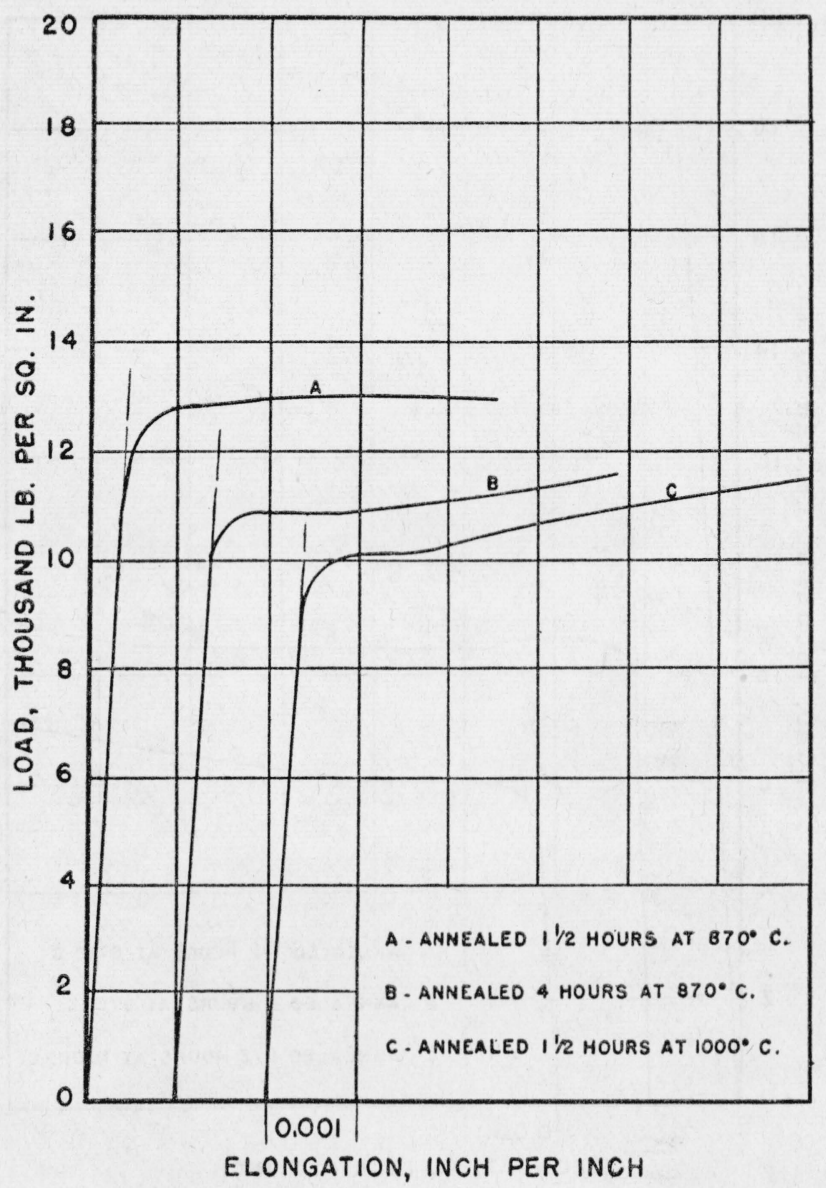

FIGURE 10.-Stress-strain curves of vacuum-melted electrolytic iron in tension.

In all cases the initial portion of the stress-strain curve was a straight line and the knee in the curve was relatively sharp. These features, together with the horizontal sections of the stress-strain curves, demonstrate that a yield point, according to the ASTM definition, is exhibited by fully annealed and partially annealed highpurity irons. When such definite indications of a yield point are obtained from iron which contains only a 0.01-percent total of impurities, it hardly seems probable that the yield point would disappear completely if all the impurities were eliminated.

The data for the tensile properties of the high-purity iron are summarized in table 5. The high-purity iron is weaker and more ductile than the electrolytic iron, and these differences are particularly noticeable when both materials are in the fully annealed condition. The tensile strengths of the fully annealed high-purity iron ranged from 27,700 to $29,900 \mathrm{lb} / \mathrm{in}^{2}$ as compared with 35,300 to $35,700 \mathrm{lb} / \mathrm{in}^{2}$ for the electrolytic iron after similar heat treatment. Differences in the grain size before and after the specimens were annealed undoubt- 


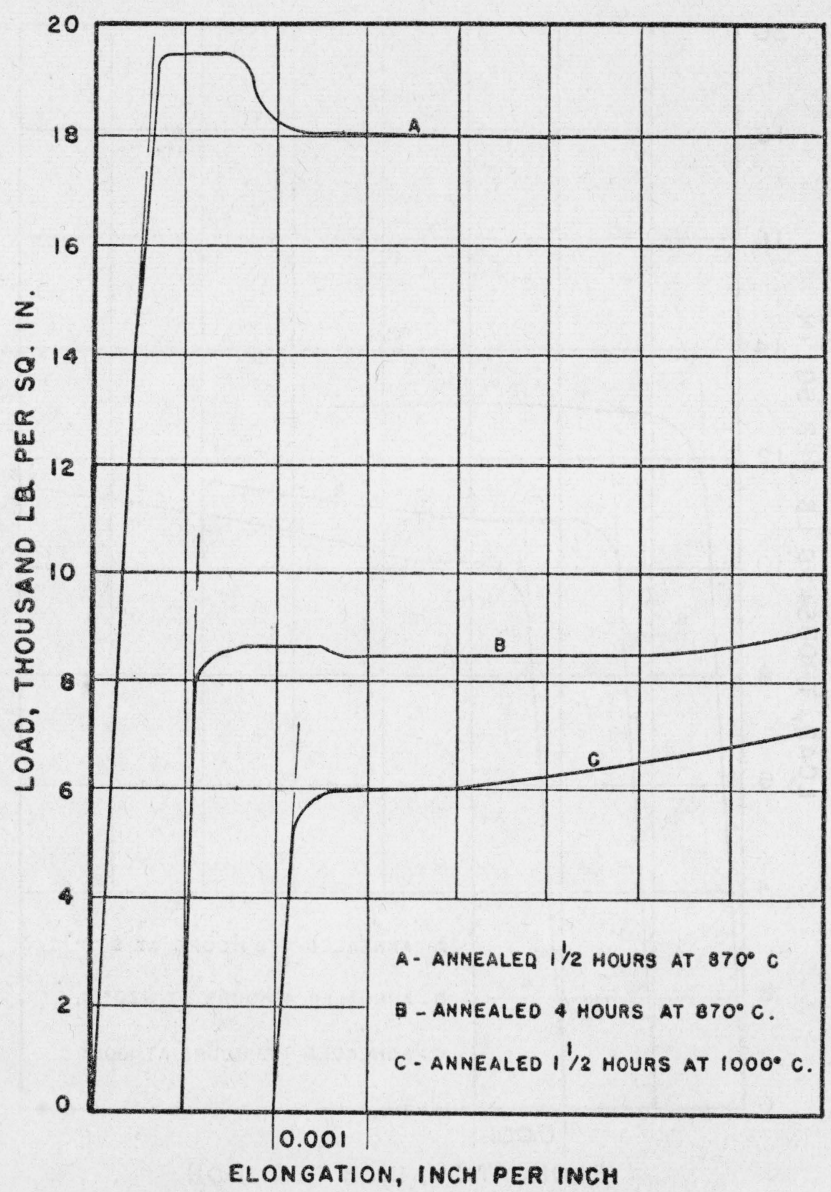

FIGURE 11.-The presence of a "yield point" in high-purity iron is demonstrated by the shape of the stress-strain curves.

edly affected their tensile properties. The electrolytic iron was moderately coarse-grained, according to microscopic observations, and this is also indicated by the slightly roughened surface of the fractured tensile specimens, as illustrated at the top of figure 12 . The grains in the high-purity iron were much larger, according to microscopic observations. This caused a pronounced roughening of the surface of most of the tensile specimens of the high-purity iron, as illustrated at the bottom of figure 12 .

Adcock and Bristow [4] reported values ranging from 20,400 to $26,700 \mathrm{lb} / \mathrm{in}^{2}$ for the tensile strength of their high-purity iron. They did not specify the previous heat treatment, but the description of the fractured edge of the specimen which broke at the low value of 20,400 pounds suggests that this rod was essentially monocrystalline in the area of fracture. 

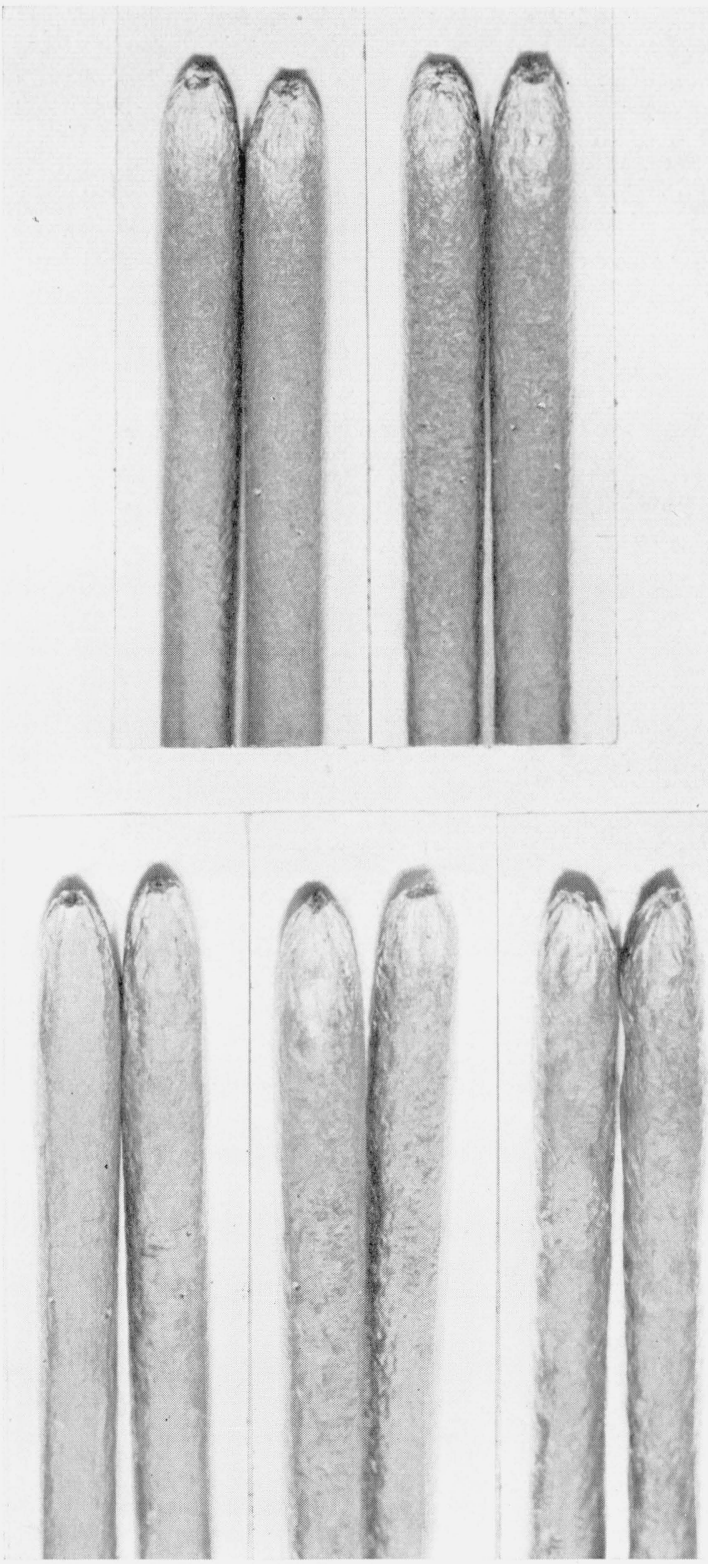

Figure 12.-Appearance of the surface indicated the grain size of fractured tensile specimens.

The two specimens at the top are electrolytic iron; the three at the bottom are high-purity iron. 
TABLE 5.-Tensile properties of high-purity iron and vacuum-melted electrolytic iron

\begin{tabular}{|c|c|c|c|c|c|c|}
\hline \multicolumn{2}{|c|}{$\begin{array}{l}\text { Annealing } \\
\text { treatment }\end{array}$} & \multirow{2}{*}{$\begin{array}{l}\text { Number } \\
\text { of speci- } \\
\text { mens } \\
\text { tested }\end{array}$} & \multirow{2}{*}{$\begin{array}{l}\text { Ultimate tensile } \\
\text { strength }\end{array}$} & \multirow{2}{*}{$\begin{array}{l}\text { Yield strength at } \\
0.2 \text {-percent offset }\end{array}$} & \multirow{2}{*}{$\begin{array}{l}\text { Reduction } \\
\text { in area }\end{array}$} & \multirow{2}{*}{$\begin{array}{l}\text { Elongation } \\
\text { in } 2 \text { inches }\end{array}$} \\
\hline Temp. & Time & & & & & \\
\hline \multicolumn{7}{|c|}{ High-purity iron } \\
\hline $\begin{array}{r}\circ C \\
870 \\
870 \\
1,000\end{array}$ & $\begin{array}{c}\text { Hours } \\
11 / 2 \\
4 \\
11 / 2\end{array}$ & $\begin{array}{l}4 \\
2 \\
3\end{array}$ & $\begin{array}{c}l b / \text { in }^{2} \\
29,500 \text { to } 36,500 \\
28,500 \text { to } 29,700 \\
27,700 \text { to } 29,900\end{array}$ & $\begin{array}{c}l b / \text { in }^{2} \\
12,500 \text { to } 18,600 \\
8,100 \text { to } 8,600 \\
6,000 \text { to } 7,800\end{array}$ & $\begin{array}{c}\% \\
81 \text { to } 91 \\
85 \text { to } 94 \\
91 \text { to } 93\end{array}$ & $\begin{array}{c}\% \\
37 \text { to } 42 \\
36 \text { to } 46 \\
36 \text { to } 41\end{array}$ \\
\hline \multicolumn{7}{|c|}{ Vacuum-melted electrolyticiron } \\
\hline $\begin{array}{r}870 \\
870 \\
1,000\end{array}$ & $\begin{array}{l}11 / 2 \\
4 \\
11 / 2\end{array}$ & $\begin{array}{l}7 \\
2 \\
2\end{array}$ & $\begin{array}{l}35,500 \text { to } 36,500 \\
34,700 \text { to } 35,300 \\
35,300 \text { to } 35,700\end{array}$ & $\begin{array}{r}9,600 \text { to } 12,900 \\
11,100 \text { to } 12,700 \\
10,200 \text { to } 10,500\end{array}$ & $\begin{array}{l}76 \text { to } 83 \\
85 \text { to } 86 \\
80 \text { to } 81\end{array}$ & $\begin{array}{r}32 \text { to } 38 \\
33 \\
31 \text { to } 32\end{array}$ \\
\hline
\end{tabular}

The yield strengths of our high-purity iron, for 0.2-percent elongation in 2 inches, ranged from 25 to 50 percent of the ultimate tensile strength. The reduction in area was greater than 90 percent for the fully annealed material and was somewhat lower for the incompletely annealed specimens. The values for the elongation in 2 inches ranged from 35 to 45 percent, with little difference between the fully annealed and the partially annealed specimens.

\section{INDENTATION HARDNESS}

Brinell indentations, with a $1 / 16$-inch ball and $15-\mathrm{kg}$ load, on the surface of furnace-cooled ingot 4 yielded results which ranged from 46 to $51 \mathrm{BHN}$, with an occasional value as low as 43 or as high as 58 . The average of all the determinations was 49 BHN. Fully annealed material also was available in the form of rods $1 / 2$ inch in diameter, which had been annealed for $1 \frac{1 / 4}{4}$ hours at $1,000^{\circ} \mathrm{C}$. Hardness determinations on the ends of these rods, with a Vickers diamond-pyramid indenter under a load of $15 \mathrm{~kg}$, ranged from 46 to 54 , with an average value of $49 \mathrm{VN}$. These results indice te that the indentation hardness number of fully annealed high-purity iron is about 49 in either Brinell or Vickers units. Almost identical values were obtained by Adcock and Bristow [4] from their best iron after annealing for 2 hours at $950^{\circ} \mathrm{C}$.

The high-purity iron hardens readily even under light working, as was demonstrated by the Brinell numbers obtained from the polished faces of the split ingots shown in figure 1 . The ingots were sawed, the surface was flattened by grinding, and was then polished and etched. After this treatment, the Brinell numbers varied widely from grain to grain, presumably reflecting the response of different orientations to the sawing, grinding, and polishing. The average of a number of determinations with a 1/10-inch ball and $15-\mathrm{kg}$ load was $79 \mathrm{BHN}$, which is considerably higher than the average (49 BHN) of determinations on unworked surfaces of the same ingot. Cold work by swaging produced still higher hardness numbers. Rods which had been reduced about 20 percent by swaging yielded Brinell numbers between 95 and 120 . When these rods were annealed at $870^{\circ} \mathrm{C}$, the Brinell number was reduced to about 85 in $1 \frac{1}{2}$ hours and to about 
60 in 4 hours, but full annealing was obtained only when the rods were heated above the $A_{3}$ point.

\section{MODULUS OF ELASTICITY ${ }^{8}$}

The modulus of elasticity of high-purity iron and of vacuum-melted electrolytic iron was determined from simultaneous stress-strain and stress-set curves, with progressively increasing loads, as described by McAdam and Mebs [25]. The results obtained from four swaged rods, representing three ingots of high-purity iron, ranged from 27.2 to 29.5 million pounds per square inch, as recorded in table 6 . Annealing the rods for $1 \frac{1}{2}$ hours at $870^{\circ} \mathrm{C}$ raised the value for the modulus slightly in some cases and definitely in others. The mean value from the four rods was increased from 28.2 to 28.9 by annealing. The precision of a single determination by this method was about \pm 0.5 million pounds per square inch, as is shown by the values 27.2 and 28.1 obtained from duplicate rods of the same material.

TABLE 6.-Modulus of elasticity of high-purity iron and electrolytic iron

\begin{tabular}{|c|c|c|}
\hline \multirow{2}{*}{ Ingot } & \multicolumn{2}{|c|}{ Modulus of elasticity } \\
\hline & Cold-worked & $\begin{array}{l}\text { Annealed 11/2 } \\
\text { hours at } 870^{\circ} \mathbf{C}\end{array}$ \\
\hline \multicolumn{3}{|c|}{ High-purity iron } \\
\hline $18 \mathrm{a}_{1}$ & $\begin{array}{c}l b / \text { in }^{2} \times 10^{-6} \\
27.9 \\
27.2 \\
28.1 \\
29.5\end{array}$ & $\begin{array}{l}l b / \text { in }^{2} \times 10^{-6} \\
27.9 \\
27.9 \\
28.7 \\
30.0\end{array}$ \\
\hline \multicolumn{3}{|c|}{ Electrolytic iron } \\
\hline 3a 1 (1 & $\begin{array}{l}30.0 \\
29.5 \\
29.8 \\
29.8\end{array}$ & $\begin{array}{l}31.0 \\
30.5 \\
29.7 \\
\end{array}$ \\
\hline
\end{tabular}

The results from four rods of electrolytic iron, as recorded in table 6, show that the elastic modulus of this material is higher than that of the high-purity iron by at least one million pounds. Annealing at $870^{\circ}$ $\mathrm{C}$ also tended to increase the modulus of the electrolytic iron. The determinations on the electrolytic iron are uniformly higher and the four determinations are more closely grouped than for the corresponding determinations on the high-purity iron. These differences may be associated with two obvious differences in the two groups of specimens: (1) the total of impurities in the electrolytic iron, about 0.04 percent, is greater; and (2) the grain size is appreciably greater in the high-purity iron.

Consideration of these data and the results reported by Adcock and Bristow [4] leads to the conclusion that Young's modulus for highpurity iron is approximately $28.5 \pm 0.5$ million pounds per square inch.

\footnotetext{
8 The determinations of the modulus of elasticity were made with the cooperation of R. W. Mebs, of the Metallurgical Division of this Bureau.
} 


\section{ELECTRICAL PROPERTIES}

\section{RESISTIVITY 9}

The resistivities of specimens from six of the high-purity iron ingots were determined by the double-bridge method. The specimens, 2 $\mathrm{mm}$ in diameter and about 1 meter long, were annealed in vacuum for 15 minutes at $850^{\circ} \mathrm{C}$. Two were reannealed at $850^{\circ} \mathrm{C}$ for 1 hour with no appreciable change in the resistivity. The results are recorded in table 7.

These values for resistivity are the lowest that have been obtained for high-purity iron at this Bureau and are somewhat below the rounded value 9.8 microhm-cm selected as the resistivity of "pure" iron at $20^{\circ} \mathrm{C}$ from the results available up to 1935 [1]. Since then Adcock and Bristow [4] reported 9.84 and 9.88 microhm-cm at $20^{\circ} \mathrm{C}$ for the resistivity of the purest iron prepared at the National Physical Laboratory, and values of $9.90,9.40$, and 9.75 for less pure irons. These latter two results are in conflict with the usually accepted belief that a decrease in resistivity accompanies an increase in purity in a metal.

TABLE 7.-Electrical properties of high-purity iron

\begin{tabular}{|c|c|c|c|c|}
\hline Ingot & $\begin{array}{c}\text { Total } \\
\text { impurities }\end{array}$ & $\begin{array}{c}\text { Electrical } \\
\text { resistivity at } \\
20^{\circ} \mathrm{C} \text { (Thomas } \\
\text { and Cooter) }\end{array}$ & $\begin{array}{l}\text { Fundamental } \\
\text { coefficient } \\
0^{\circ} \text { to } 100^{\circ} \mathrm{C} \\
\text { (Wensel and } \\
\text { Roeser) }\end{array}$ & $\begin{array}{l}\text { Thermal } \\
\text { electromotive } \\
\text { force against } \\
\text { platinum at } \\
100^{\circ} \mathrm{C} \text { (Dahl) }\end{array}$ \\
\hline $\begin{array}{l}2 \\
7 \\
14 \\
11 \\
19 \\
6\end{array}$ & \multirow[t]{2}{*}{$\begin{array}{l}\% \\
<0.0085 \\
<.0089 \\
<.0089 \\
<.0098 \\
<.0106 \\
<.0117\end{array}$} & $\begin{array}{r}\text { Microhm-cm } \\
9.69 \\
9.72 \\
9.71 \\
9.70 \\
9.72 \\
9.71\end{array}$ & $\begin{array}{r}\text { Ohms per }{ }^{\circ} \mathrm{C} \\
\text { per ohm at } 0^{\circ} \mathrm{C} \\
0.00652 \\
.00650 \\
.00652 \\
.00652 \\
.00650 \\
.00652 \\
\end{array}$ & $\begin{array}{r}\text { Microvolts } \\
1981 \\
1976 \\
1982 \\
1981 \\
1978 \\
1983\end{array}$ \\
\hline A verage & & 9.71 & .00651 & 1980 \\
\hline
\end{tabular}

No correlation could be made between the values for resistivity and the amounts of total or individual impurities in our irons.

\section{TEMPERATURE COEFFICIENT OF RESISTIVITY 10}

The temperature coefficient of electrical resistivity over the temperature range $0^{\circ}$ to $100^{\circ} \mathrm{C},\left(R_{100}-R_{0}\right) / 100 R_{0}$, usually termed the fundamental temperature coefficient, has been considered to be a measure of the purity of a metal, the higher the purity the higher the coefficient; but Wensel and Roeser found that the fundamental coefficient of resistivity of iron was appreciably affected by the prior thermal history of the specimens. In experiments with some of the preliminary products of high-purity iron, they found, as shown in figure 13, that the fundamental coefficient of wires $0.5 \mathrm{~mm}$ in diameter increased with increasing temperature of annealing up to $600^{\circ} \mathrm{C}$, remained approximately constant for annealing temperatures between

\footnotetext{
-The determinations of electrical resistivity were made by J. L. Thomas and I. L. Cooter, of the Electrical Division of this Bureau.

${ }_{10}$ The determinations of the temperature coefficient of resistivity were made by Wm. F. Roeser, of the Heat and Power Division of this Bureau.
} 


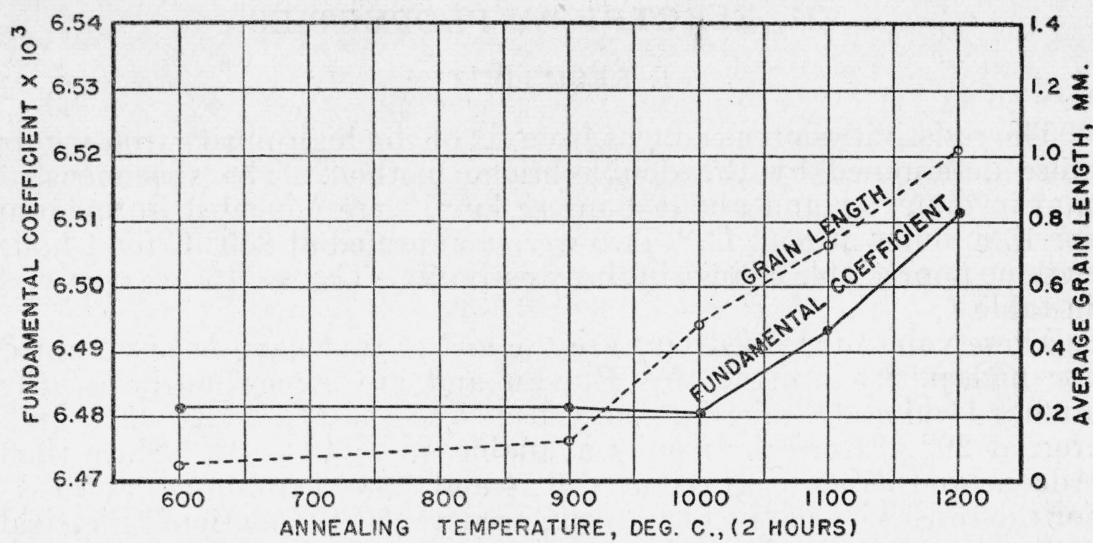

FIGURE 13.-Relation between annealing temperature, grain size, and fundamental coefficient of resistivity $\left(R_{100}-R_{0}\right) / 100 R_{0}$, of high-purity iron wire $0.5 \mathrm{~mm}$ in diameter) Wensel and Roeser.

$600^{\circ}$ and $1,000^{\circ} \mathrm{C}$, and again increased with increasing temperatures of annealing above $1,000^{\circ} \mathrm{C}$. Microscopic studies indicated that this final rise in the fundamental coefficient was associated with increases in the grain size when the iron was annealed at temperatures above $A_{3}$, although the data in figure 13 show that annealing at $1,000^{\circ} \mathrm{C}$ increased the grain size without affecting the coefficient. The effect of the annealing temperature on the fundamental coefficient was exaggerated when wires of smaller diameter were used, and with $0.2-\mathrm{mm}$ wire reproducible results could not be obtained even in the $600^{\circ}$ to $1,000^{\circ} \mathrm{C}$ range. Certain portions of the finer wires consisted of single crystals, and it is probable that the large grain size in proportion to the diameter of the wire was the cause of the erratic results.

The data indicate that when reproducible values for the fundamental coefficient are desired, for the purpose of comparing purity, the specimens should be annealed at a temperature between $600^{\circ}$ and $1,000^{\circ} \mathrm{C}$. For this reason determinations of the fundamental coefficient of the high-purity irons were made on wire specimens $0.5 \mathrm{~mm}$ in diameter which had been annealed for 2 hours at $800^{\circ} \mathrm{C}$ in vacuum. The values recorded in table 7 show that the fundamental coefficients of specimens of six of the high-purity ingots ranged from 0.00650 to 0.00652 , with an average value of $0.00651 \mathrm{ohm}$ per $0 /{ }^{\circ} \mathrm{C}$ per ohm at $0^{\circ} \mathrm{C}$. The variations within this range could not be correlated with the compositions of the ingots nor with the resistivity data from other specimens of the same ingots.

This value, 0.00651 , is in agreement with the value 0.00648 which may be computed from the data reported by Adcock and Bristow [4] for the resistivity of their best iron. Three higher values for the fundamental temperature coefficient of resistivity of iron are found in the literature: 0.00657 and 0.00821 , reported by Meyer [26] in 1911 ; and 0.00657 , reported by Holborn [27] in 1919. Meyer's results are cited in the International Critical Tables, but there are indications that his temperature and resistance measurements were erroneous. Meyer's resistance measurements on "Kahlbaum's nitrate iron," from which the high coefficient 0.00821 was derived, differ appreciably from the closely grouped results of other investigators who 
used the same material. Holborn's value of 0.00657 is the highest of four values obtained on a specimen of "Kahlbaum's nitrate iron" annealed at $500^{\circ} \mathrm{C}$ for several minutes, the other values being 0.00643 , 0.00638 , and 0.00635 . Determinations of the temperature coefficients at temperatures up to $511^{\circ} \mathrm{C}$ were alternated with the determinations of the fundamental coefficient. In view of Roeser's observation, the variation in values may have resulted from the varying temperatures to which the specimen was heated. Holborn's highest value, 0.00657 , was not reproducible and probably applied only to a particular specimen which had been subjected to unusual heat treatment.

It appears, therefore, that 0.00651 is the highest reproducible value that has been obtained for the fundamental coefficient of resistivity of high-purity iron. Higher values can be obtained by annealing the specimens at higher temperatures, but the results are not easily reproducible. The temperature coefficient of resistivity may be used as an index of the purity of different specimens of iron which have received the same heat treatment, and the optimum conditions for the heat treatment of iron, to produce the maximum reproducible coefficients, are annealing for 2 hours or more at about $800^{\circ} \mathrm{C}$ in vacuum.

\section{THERMAL ELECTROMOTIVE FORCE 11}

Observations in the Heat and Power Division of this Bureau indicated that the thermal electromotive force of iron against platinum could be correlated with the fundamental coefficient of resistivity, both increasing with purity. The thermal electromotive force of iron against platinum, then, also would serve as an indication of comparative purity. Values for the thermal electromotive force are comparable only when obtained at identical temperatures; hence the readily reproducible temperatures $100^{\circ}$ and $0^{\circ} \mathrm{C}$ were used for the hot and cold junctions during the work in which the correlation between the thermal electromotive force and the temperature coefficient was obtained.

Determinations of the thermal electromotive force against the Bureau's platinum standard, $\mathrm{Pt} 27$, for the fundamental temperature interval $0^{\circ}$ to $100^{\circ} \mathrm{C}$ were made with specimens of the same wires, $05 \mathrm{~mm}$ in diameter and previously annealed for 2 hours at $800^{\circ} \mathrm{C}$ in vacuum, which had been used for the resistivity determinations. The results ranged from 1,976 to 1,983 microvolts, as shown in table 7 , with no apparent correlation between the variations in the thermal electromotive force and variations in the impurities or other properties except the fundamental coefficient of resistivity.

Values of 1837 microvolts for basic open-hearth iron with a 0.17 percent total of impurities and 1966 microvolts for electrolytic iron with an 0.018-percent total of impurities have been recorded. The values from the high-purity iron, with about 0.01-percent total of impurities, are higher than the value for electrolytic iron and appreciably higher than the value for open-hearth iron.

\section{MAGNETIC PROPERTIES}

The magnetic properties of iron may be classed in two groups: (1) the magnetic saturation induction and the Curie point, which

11 The measurements of thermal electromotive force were made by A. I. Dahl, of the Heat and Power Division of this Bureau.

$451601-42-7$ 
are characteristics of the element and are not influenced by its condition and only slightly by impurities; and (2) permeability, hysteresis loss, coercivity, remanence, and similar properties which are greatly affected by mechanical and thermal treatment of the specimen and by impurities. Determinations of properties in both groups were made on specimens of our high-purity iron.

\section{MAGNETIC SATURATION INDUCTION 12}

Swaged bars one-quarter inch in diameter, prepared from eight of the ingots, were ground to a circular, uniform diameter of $6 \mathrm{~mm}$ and then were cut to lengths of $8 \mathrm{~cm}$. After determinations had been made on the bars in the cold-worked condition, two of them were annealed in vacuum, one at $870^{\circ} \mathrm{C}$ for 1 hour and the other at $1,020^{\circ}$ $\mathrm{C}$ for 1 hour. Redeterminations of the saturation induction showed that the change in both cases was insignificant, that is, well within the limits of experimental error. Sanford and Bennett applied corrections to the data for (1) nonuniformity of area of the samples, (2) delayed impulse, and (3) impurities. The total of these corrections in each case was about 0.05 kilogauss, and 80 percent of this was the correction for delayed impulse. The correction for impurities was only 0.004 kilogauss, which is less than the probable error in magnetic measurements of the order of 21 kilogausses.

TABLE 8.-Corrected values for the magnetic saturation induction of high-purity iron at $25^{\circ} \mathrm{C}$, based upon a density of $7.874 \mathrm{~g} / \mathrm{cm}^{3}$ (Sanford and Bennett)

\begin{tabular}{|c|c|}
\hline Ingot & $\begin{array}{l}\text { Saturation } \\
\text { induction }\end{array}$ \\
\hline & $\begin{array}{l}\text { Kiloyausses } \\
21.576\end{array}$ \\
\hline $\begin{array}{l}3{ }^{a}-- \\
6--\end{array}$ & $\begin{array}{l}21.573 \\
21.584\end{array}$ \\
\hline - & 21.575 \\
\hline $8 \mathrm{~b}$ & $\begin{array}{l}21.591 \\
21.590\end{array}$ \\
\hline $12-\cdots$ & 21.593 \\
\hline 13 13- & $\begin{array}{l}21.568 \\
-11562\end{array}$ \\
\hline $\begin{array}{l}14 \\
18\end{array}$ & $\begin{array}{l}21.562 \\
21.569\end{array}$ \\
\hline Mean & 21.578 \\
\hline
\end{tabular}

a Annealed 1 hour at $870^{\circ} \mathrm{C}$.

b Annealed 1 hour at $1,020^{\circ} \mathrm{C}$.

The corrected values for saturation intensity are listed in table 8 . These values are in good agreement with the most reliable of the previous determinations [29], [30], [31], [32], according to Sanford and Bennett. They state that "It seems safe to conclude, therefore, that the saturation value for pure iron at $25^{\circ} \mathrm{C}$ and based upon a density of $7.874 \mathrm{~g} / \mathrm{cm}^{3}$ is $21.58 \pm 0.01$ kilogausses."

\section{COERCIVITY AND MAXIMUM PERMEABILITY ${ }^{13}$}

Specimens for these determinations were prepared by cold-rolling sections of four of the high-purity ingots to sheets from which were cut rings $1 \frac{11}{8}$ inches in outside diameter, $15 / 16$ inch in inside diameter,

\footnotetext{
12 The determinations of magnetic saturation induction were made by R. L. Sanford and E. G. Bennett, of the Electrical Division of this Bureau, as described eleswhere [28].

${ }_{13}$ These properties were determined by P. P. Cioffi, of the Bell Telephone Laboratories.
} 
and 0.062 inch thick. Before determining the magnetic properties of the specimens, they were subjected to four different heat treatments which were designed to obtain different combinations of relief from mechanical strains, recrystallization effects, and elimination of nonmetallic impurities through the action of hydrogen at high temperatures.

The results recorded in table 9 show that prolonged annealing at high temperatures, where recrystallization was complete and elimination of nonmetallic impurities by hydrogen probably occurred, produced better magnetic properties than were obtained from duplicate specimens which had received only a strain-relieving anneal at low temperatures. The beneficial effect of annealing at intermediate temperatures sometimes is neutralized by other factors, perhaps by structural differences, such as preferred orientation. There is no apparent relation between purity and permeability or coercive force.

The highest maximum permeability, 88,400 , was obtained on a specimen of ingot 4 annealed at $1,450^{\circ} \mathrm{C}$. This specimen had a coercive force of 0.045 oersted, a residual induction of 11,830 gausses and a hysteresis loss of 150 ergs per cubic centimeter per cycle, all for a $B_{\max }$ of 15,080 gausses.

TABLE 9-Maximum permeability and coercive force of NBS high-purity iron (Cioffi)

\begin{tabular}{|c|c|c|c|c|}
\hline \multicolumn{5}{|c|}{ Maximum permeability } \\
\hline Heat treatment (in hydrogen) & Iron 4 & Iron 12 & Iron 14 & Iron 18 \\
\hline 18 hours at $880^{\circ} \mathrm{C}_{\ldots}$ & 68,100 & 69,100 & $18,4 \mathrm{C} 0$ & 25,600 \\
\hline $\left.\begin{array}{l}4 \text { hours at } 1,200^{\circ} \mathrm{C} \\
18 \text { hours at } 880^{\circ} \mathrm{C}\end{array}\right\}$ & 49,700 & 62,300 & 36,800 & 44,100 \\
\hline $\left.\begin{array}{l}20 \text { hours at } 1,200^{\circ} \mathrm{C} \\
18 \text { hours at } 880^{\circ} \mathrm{C}\end{array}\right\} \ldots$ & 47,500 & 69,500 & 61,400 & 61,100 \\
\hline $\left.\begin{array}{l}18 \text { hours at } 1,450^{\circ} \mathrm{C} \\
18 \text { hours at } 880^{\circ} \mathrm{C}\end{array}\right\} \ldots$ & 88,400 & 87,600 & 65,400 & 80,100 \\
\hline \multicolumn{5}{|c|}{ Coercive force ( $B_{\max }$ about 15,500$)$} \\
\hline 18 hours at $880^{\circ} \mathrm{C}_{-}$. & $\begin{array}{l}\text { Otrsted } \\
\quad 0.0946\end{array}$ & $\begin{array}{l}\text { Oersted } \\
\quad 0.0931\end{array}$ & $\begin{array}{l}\text { Oersied } \\
0.130\end{array}$ & $\begin{array}{l}\text { Oersted } \\
\quad 0.260\end{array}$ \\
\hline $\left.\begin{array}{l}4 \text { hours at } 1,200^{\circ} \mathrm{C} \\
18 \text { hours at } 880^{\circ} \mathrm{C}\end{array}\right\}$ & .094 & .0961 & .0961 & .0946 \\
\hline $\left.\begin{array}{l}20 \text { hours at } 1,200^{\circ} \mathrm{C} \\
18 \text { hours at } 880^{\circ} \mathrm{C}\end{array}\right\}$ & .109 & .0848 & .0863 & .080 \\
\hline $\left.\begin{array}{l}18 \text { hours at } 1,450^{\circ} \mathrm{C} \\
18 \text { hours at } 880^{\circ} \mathrm{C}\end{array}\right\} \ldots$. & .0450 & .0526 & .0481 & .0535 \\
\hline
\end{tabular}

A comparative evaluation of these results is impossible because these properties are properties of the specimen, not of the material, and are pronouncedly affected by factors such as the shape and size of the specimen, the previous thermal and mechanical treatment, the structure, including the size and orientation of the grains, and the condition under which the determination is made. Adcock and Bristow [4] reported values ranging from 14,360 to 31,400 for the maximum permeability and 0.115 to 0.271 oersted for the coercive force of their high-purity iron. The variation in magnetic properties 
and the lack of correlation with purity were similar to those encountered in the present work. These properties of high-purity iron are superior to those of ordinary magnetic iron, which, according to Cioffi, has a maximum permeability of about 7,000 and a coercive force of about 1.0 oersted. However, the values for maximum permeability obtained from our high-purity iron and from that of Adcock and Bristow are far from being the highest that have been reported for iron. Maximum permeabilities in excess of 200,000 were obtained from thicker specimens of polycrystalline iron by Cioffi [33] and by Yensen and Ziegler [34]. Even higher values have been obtained from single crystals of iron-for example, Cioffi and Boothby [35] obtained a maximum permeability of $1,450,000$ in the direction of the cubic axis of a single crystal of "hydrogen-purified" carbonyl iron.

The results obtained from the high-purity irons confirm the belief that such magnetic properties as permeability and coercivity are influenced by factors other than purity, and hence are not satisfactory criteria of purity in iron.

\section{SUMMARY}

The results of the determinations of properties of the Bureau's high-purity iron (0.01-percent total of impurities) may be summarized as follows:

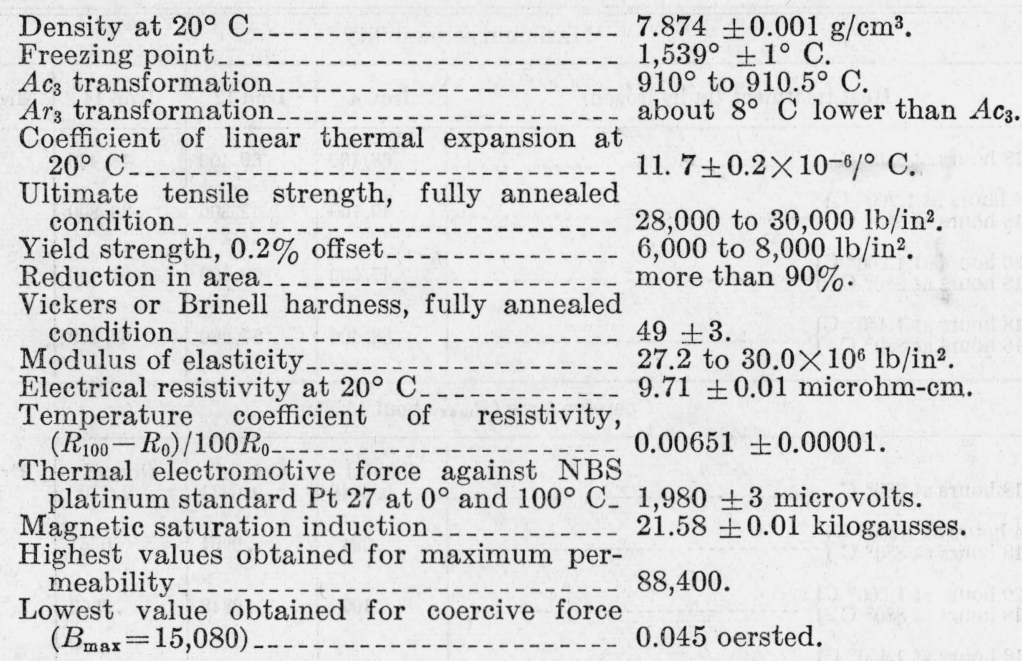

The effect of variations in the amounts of individual or total impurities, within the range of composition of these ingots, was less than the experimental error of the determinations that were made. Variations in the composition of this high-purity material could not be correlated with variations in the results of any of these determinations.

The authors acknowledge their indebtedness to the many workers at the Bureau and elsewhere, as indicated in the text, who contributed to this determination of the properties of high-purity iron. 


\section{REFERENCES}

[1] H. E. Cleaves and J. G. Thompson, The Metal-Iron (McGraw-Hill Book Company, New York, N. Y., 1935).

[2] H. E. Cleaves and J. G. Thompson, J. Research NBS 18, 595 (1937) RP996.

[3] J. G. Thompson and H. E. Cleaves, J. Research NBS 23, 163 (1939) RP1226.

[4] F. Adcock and C. A. Bristow, Proc. Royal Soc. (London) [A] 153, 172(1935-36).

[5] F. K. Naumann, Tech. Mitt. Krupp 1, 207 (1938).

[6] G. A. Ellinger and J. S. Acken, Trans. Am. Soc. Metals 2\%, 382 (1939).

[7] G. F. Meyer, G. D. Rahrer, and J. R. Vilella, Metals \& Alloys 13, 424 (1941).

[8] W. C. Elmore, J. Applied Physics 10, 724 (1939).

[9[ Wm. F. Roeser and H. T. Wensel, J. Research NBS 26, 273 (1941) RP1375.

[10] J. Chipman and S. Marshall, Temperature, Its Measurement and Control, p. 958 (Reinhold Publishing Corporation, New York, N. Y., 1941).

[11] C. Wells, R. A. Ackley, and R. F. Mehl, Trans. Am. Soc. Metals 24, 46 (1936).

[12] H. Esser, J. Iron \& Steel Inst. (London), Carnegie Schol. Mem. 25, 213 (1936). Discussion, J. Iron Steel Inst. (London) 135, 421 (1937).

[13] H. Esser and H. Eusterbrock, Arch. Eisenhüttenw. 14, 341 (1941).

[14] S. D. Smith, Trans. Am. Soc. Metals 26, 255 (1938).

[15] A. P. Wangsgard, Trans. Am. Soc. Metals (1941) (Preprint).

[16] H. Scott and J. R. Freeman, Jr., BS Sci. Papers 15, 317 (1919-20) S348.

[17] J. B. Austin, Physics 3, 240 (1932).

[18] B. A. Rogers and K. O. Stamm, Am. Inst. Min. Met. Engrs., Tech. Pub. No. 1388, Metals, Tech. (October 1941).

[19] W. Souder and P. Hidnert, BS Sci. Pap. 21, 1 (1926-27) S524.

[20] F. C. Nix and D. MacNair, Phys. Rev. 60, 597 (1941).

[21] J. B. Austin and R. H. Pierce, Jr., Trans. Am. Soc. Metals 22, 447 (1934).

[22] G. E. Merritt, BS J. Research 10, 59 (1933) RP515.

[23] J. B. Saunders, J. Research NBS 23, 179 (1939) RP1227.

[24] Am. Soc. Testing Materials, Standards, pt. 1, Metals, p. 761 (1939).

[25] D. J. McAdam, Jr. and R. W. Mebs, NACA Tech. Report No. 670 (1939).

[26] A. R. Meyer, Verhandl. Deut. Physik. Ges. 13, 680 (1911).

[27] L. Holborn, Ann. Physik [4], 59, 145 (1919).

[28] R. L. Sanford and E. G. Bennett, J. Research NBS 26, 1 (1941) RP1354.

[29] W. Steinhaus, A. Kussman, and E. Schoen, Physik. Z. 38, 777 (1937).

[30] E. Gumlich, Wiss. Abhandl. physik. tech. Reichsanstalt 4, 267 (1918).

[31] K. Honda and S. Kaya, Sci. Rept., Tohoku Imp. Univ., Sendai, [1] 15, 721 (1926).

[32] P. Weiss and R. Forrer, Ann. Phys. 12, 279 (1929).

[33] P. P. Cioffi, Phys. Rev. 45, 742 (1934).

[34] T. D. Yensen and N. A. Ziegler, Trans. Am. Soc. Metals, 23, 556 (1935).

[35] P. P. Cioffi and O. L. Boothby, Phys. Rev. 55, 673 (1939).

Washington, February 5, 1942. 


\section{NATIONAL BUREAU OF STANDARDS,}

WASHINGTON, D. C.

Send me the Mathematical Tables marked $\mathrm{X}$ below. I enclose remittance ${ }^{1}$ to cover the cost.

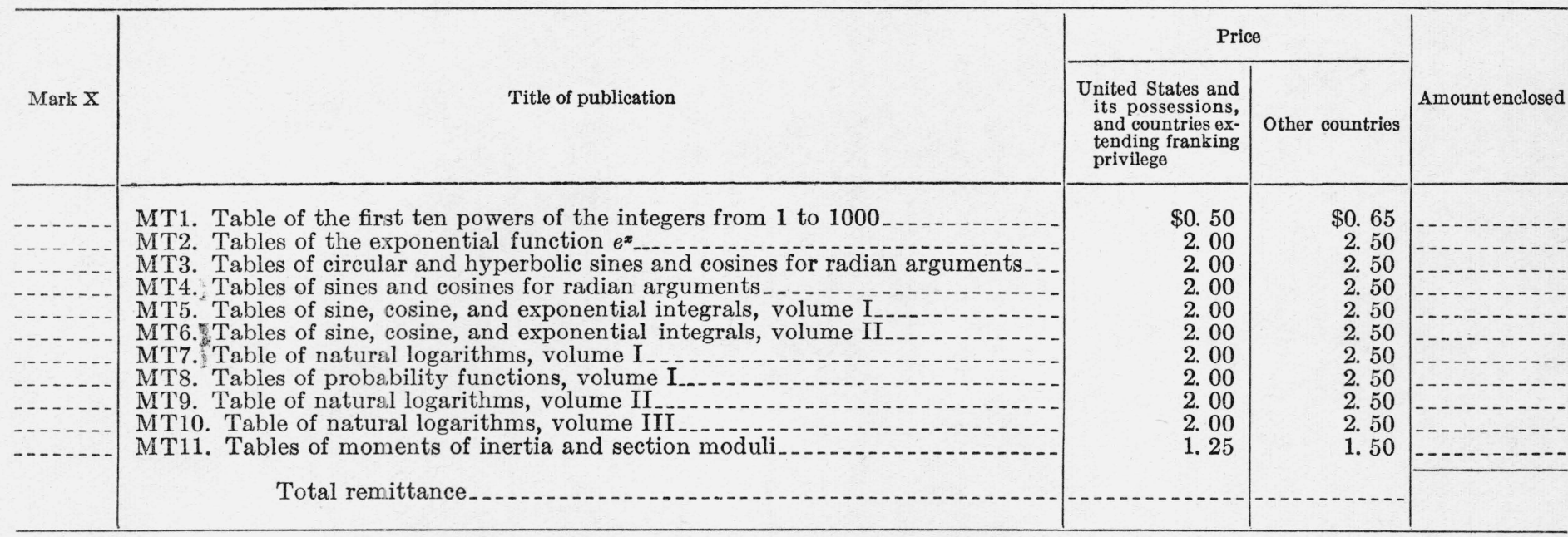

${ }^{1}$ Remittance should be in form of post-office money order, or check, and made payable to the order of the "National Bureau of Standards" in United States currency.

Send to

Number and Street

City and State 


\section{MATHEMATICAL TABLES}

Attention is invited to a series of publications which is being prepared by the Project for the Computation of Mathematical Tables conducted by the Federal Works Agency, Work Projects Administration for the City of New York under the sponsorship of the National Bureau of Standards.

To date, eleven tables have been made available through the National Bureau of Standards. These are listed below:

MT1. Table or the First Ten Powers or the Integers From 1 to 1000:

(1938) VIII +80 pages; heavy paper cover. 50 cents.

MT2. Tablas of thr Exponential Function $e^{x}$ :

The ranges and intervals of the argument and the number of decimal places in the entries are given below:

$\begin{array}{rcc}\text { Range of } x & \text { Interval of } x & \text { Decimals given } \\ -2.5000 \text { to } 1.0000 & 0.0001 & 18 \\ 1.0000 \text { to } 2.5000 & .0001 & 15 \\ 2.500 \text { to } 5.000 & .001 & 15 \\ 5.00 \text { to } 10.0 & .01 & 12\end{array}$

(1939) XV+535 pages; bound in buckram, $\$ 2.00$.

MT3. Tables of Circular and Hyperbolic Sings and Cosines for Radian Arguments:

Contains 9 decimal place values of $\sin x, \cos x, \sinh x$ and $\cosh x$ for $x$ (in radians) ranging from 0 to 2 at intervals of 0.0001 .

(1939) XVII+ 405 pages; bound in buckram, $\$ 2.00$.

MT4. Tables of Sines and Cosines for Radian Arguments:

Contains 8 decimal place values of sines and cosines for radian arguments ranging from 0 to 25 at intervals of 0.001 .

(1940) XXIX + 275 pages; bound in buckram, $\$ 2.00$.

MT5. Tables of Sine, Cosine, and Exponential Integrals, Volume I:

Values of these functions to 9 places of decimals from 0 to 2 at intervals of 0.0001 .

(1940) XXVI+444 pages; bound in buckram, $\$ 2.00$.

MT6. Tablzs or Sine, Cosine, and Exponential Integrals, Volume II:

Values of these functions to 9,10 , or 11 significant figures from 0 to 10 at intervals of 0.001 , with auxiliary tables.

(1940) XXXVII + 225 pages; bound in buckram, $\$ 2.00$.

MT7. Table or Natural Logarthms, Volume I:

Logarithms of the integers from 1 to 50,000 to 16 places of decimals.

(1941) XVIII + 501 pages; bound in buckram, $\$ 2.00$.

MT8. Tables or Probability Functions, Volume I:

Values of these functions to 15 places of decimals from 0 to 1 at intervals of 0.0001 and 1 to 5.6 at intervals of 0.001 .

(1941) XXVIII + 302 pages; bound in buckram, $\$ 2.00$.

MT9. Tabiz of Natural Logarithms, Volume II:

Logarithms of the integers from 50,000 to 100,000 to 16 places of decimals

(1941) XVIII+501 pages; bound in buckram, $\$ 2.00$. 
MT10. Table of Natural Logarithms, Volume III:

Logarithms of the decimal numbers from 0.0001 to 5.0000 , to 16 places of decimals.

(1941) XVIII + 501 pages; bound in buckram, $\$ 2.00$.

MT11. Tables of the Mombnts of Inertia and Section Moduli of Ordinary Angles, Channels, and Bulb Angles with Certain Plate Combinations.

(1941) XIII + 197 pages; bound in green cloth. $\$ 1.25$.

Payment is required in advance. Make remittance payable to the "National Bureau of Standards", and send with order, using the blank form facing page 3 of the cover.

The prices are for delivery in the United States and its possessions and in countries extending the franking privilege. To other countries the price of MT1 is 65 cents; that of MT2, MT3, MT4, MT5, MT6, MT7, MT8, MT9, and MT10 is $\$ 2.50$ each; and that of MT11, $\$ 1.50$; remittance to be made payable in United States currency.

Copies of these publications have been sent to various Government depositories throughout the country, such as public libraries in large cities, and colleges and universities, where they may be consulted.

A mailing list is maintained for those who desire to receive announcements regarding new tables as they become available. A list of the tables it is planned to publish will be sent on request. 